\title{
A VIOLENCIA COMO INSTRUMENTOS DE PODER NAS RELAÇÕES SOCIAIS E COMO INSTRUMENTO DE DOMINAÇÃO
}

\author{
Aparecida Luzia Alzira Zuin ${ }^{1}$ \\ Haruo Mizusaki²
}

\section{Resumo}

Este trabalho tem como tema o fenômeno do aumento da população carcerária feminina no sistema prisional brasileiro. Para fins de identificação do contingente de mulheres presas e análise do perfil, delimitou o estudo no caso de encarceramento feminino no estado de Rondônia, tendo como base inicial o Relatório InfopenMulheres, 2a edição, publicado pelo Ministério da Justiça e Segurança Pública e Departamento Penitenciário Nacional, em 2017, sobre a população prisional feminina por unidade da Federação, onde informa que Rondônia conta com 721 mulheres privadas de liberdade, ocupando a 16a posição da lista (2017). Analisa a Lei Maria da Penha (Lei n. 11.340/2006) na qual dispõe, conforme sua ementa, de mecanismos que tem como finalidade coibir a violência doméstica e familiar contra a mulher, nos termos do art. 226, $\$ 8^{\circ}$, da Constituição Federal de 1988, da Convenção sobre a Eliminação de Todas as Formas de Discriminação contra as Mulheres e da Convenção Interamericana para Prevenir, Punir e Erradicar a Violência contra a Mulher, dentre outras providências. Todavia, apesar do transcurso, muitos obstáculos ainda circundam a aplicação da Lei n. 11.340/2006, de ordem material (falta ou ineficácia dos serviços) e pessoal, que vão desde ao desconhecimento da Lei por parte da população, à diversidade de entendimento entre os aplicadores do direito. A pesquisa qualitativa foi realizada em duas etapas, sendo para a primeira a adoção dos procedimentos metodológicos de base documental e bibliográfica com ênfase nos Direitos Humanos e na Lei Maria da Penha; e a segunda de observação participativa, com aplicação de 24 questionários e

\footnotetext{
${ }^{1}$ Pós-Doutorado em Direito pela Uerj, Área de concentração: Direito da Cidade; Linha de pesquisa: Políticas Públicas Urbanas. Pós-Doutora em Estudos Culturais (Imaginários Urbanos; Cultura e Desenvolvimento), pelo Programa Avançado de Cultura Contemporânea (PACC) da UFRJ. Pesquisadora Associada do PACC-UFRJ. Profa. do Mestrado em Educação (Unir) e Mestrado Profissional Interdisciplinar em Direitos Humanos e Desenvolvimento da Justiça (DHJUS/UNIR/EMERON). E-mail: alazuin@gmail.com

${ }^{2}$ Mestrando do Programa de Pós-Graduação Mestrado Profissional Interdisciplinar em Direitos Humanos e Desenvolvimento da Justiça - Unir/Emeron. Docente, da Escola da Magistratura do Estado de Rondônia (EMERON). E-mail: haruomizusaki@gmail.com
} 
entrevistas feitas na Penitenciária Feminina de Ji-Paraná (RO), nos dias 17/12/2017 a 14/01/2018 e 21/01/2018, com as presidiárias que permitiram a participação, a fim de, com a coleta dos seguintes dados: estado de origem, faixa etária, cor ou raça, grau de escolaridade, estado civil, condição socioeconômica medida pelo salário mínimo vigente no Brasil, quantidade de filhos, orientação sexual, traçar o perfil sociodemográfico da população feminina privada de liberdade nesse estabelecimento penal, para análises e posteriores propostas de atendimento aos seus direitos como mulher.

Palavras-chave: Mulheres. Encarceramento. Perfil. Direitos Humanos. Lei Maria da Penha.

\section{INTRODUÇÃO}

Estudos e a realidade revelam o quanto é desafiante para toda a sociedade e para a administração do Estado administrar o sistema carcerário brasileiro. Organizações criminosas estão instaladas nas prisões e do interior da unidade prisional comandam a execução de crimes e movimentam cifras astronômicas. A população carcerária só apresenta índices crescentes, talvez reflexo dos anseios sociais de que para maior segurança da sociedade se emprega o discurso do senso comum que para melhorar a insegurança é melhor "bandido preso". Aliado a isso, a falta de recursos para o setor, a má-aplicação dos poucos recursos existentes e os desvios em razão da corrupção são os fatores que agravam o setor penitenciário. E externamente, vê-se o país obrigado a ter que cumprir protocolos internacionais por violação dos tratados, convenções, pactos e regras internacionais de direitos humanos.

Apesar de o Brasil ser signatário dos atos internacionais sobre Direitos Humanos, há uma demora significativa para a sua internalização, e muitas violações ocorrem até com certa frequência.

Segundo dados do Infopen de 2017, havia no sistema prisional brasileiro, excluídos os que cumpriam pena de prisão domiciliar e os que se encontravam sob monitoramento eletrônico, em junho de 2016, mas incluídas, aí, as mulheres, um total de 726.712 prisioneiros, para 368.049 vagas. Havia um déficit de 358.663 vagas, ou seja, a taxa de ocupação era de 197,4\% e a taxa de encarceramento geral era de 352,6 pessoas detidas para um grupo de 100.000 pessoas. Especificamente para o lugar onde a pesquisa se fixa, o estado de Rondônia apresentava uma população carcerária de 10.832 prisioneiros, para um total de vagas de 4.969 e uma taxa ocupacional de 218\%. E pelos dados do Infopen Mulheres de 2017, para o mesmo mês de referência, havia no sistema prisional brasileiro 42.355 mulheres detidas, para 27.029 vagas e uma taxa de encarceramento feminino de 156,7\% e um 
déficit de 15.326 vagas. A taxa de encarceramento feminino era de 40,6 mulheres para um grupo de 100.000 mulheres. Embora esse recorte possa chamar a atenção para o número de prisioneiros e prisioneiras e para o déficit de vagas, o que chama mais a atenção é a sua comparação com as informações que constavam no ano de 2000, que demonstra um crescimento da população carcerária masculina de $293 \%$ e o da feminina $656 \%$.

Daí surgiu o foco das atenções deste estudo, isto é, o encarceramento feminino, porém, voltado ao estado de Rondônia. A questão que se propôs a fazer para este estudo foi verificar se a invisibilidade das prisioneiras e se os fundamentos da prisão são iguais a todas; quais os crimes cometidos e por quais motivos levaram a cometer. Dentre os objetivos foi identificar os motivos pelos quais levaram essas pessoas a cometerem crimes, por isso, a necessidade de se distinguir a hipótese em que a mulher é efetivamente vítima de violência de gênero no âmbito doméstico, daquelas outras situações em que ela atua como autora, coautora ou partícipe de infrações penais, para que o resultado no tratamento seja diferenciado e mais justo a cada situação que são efetivamente distintas; porque a pressuposição é que algumas mulheres são coagidas a praticarem crimes em favor de seus companheiros (ou até mesmo com eles), ou a favor de quem detenha um poderio sobre elas, em especial, de natureza econômica ou afetiva, consequentemente, não podem ser penalizadas da mesma forma que aquelas em circunstâncias diferentes. A pesquisa qualitativa foi realizada em duas etapas, sendo para a primeira a adoção dos procedimentos metodológicos de base documental e bibliográfica com ênfase nos Direitos Humanos e na Lei Maria da Penha; e a segunda de observação participativa, com aplicação de 24 questionários e entrevistas feitas na Penitenciária Feminina de Ji-Paraná (RO), nos dias 17/12/2017 a 14/01/2018 e 21/01/2018, com as presidiárias que permitiram a participação, a fim de, com a coleta dos seguintes dados: estado de origem, faixa etária, cor ou raça, grau de escolaridade, estado civil, composição familiar, religião, condição socioeconômica medida pelo salário mínimo vigente no Brasil, quantidade de filhos, orientação sexual, traçar o perfil sociodemográfico da população feminina privada de liberdade nesse estabelecimento penal, para análises e posteriores propostas de atendimento aos seus direitos como mulher.

\section{AS MULHERES E A ESTRUTURA MASCULINA DO CÁRCERE}

Segundo os dados do Sistema de Informações e Estatísticas do Sistema Penitenciário Brasileiro - Infopen Mulheres/2016, do Ministério da Justiça- MJ, em 2016 havia no sistema prisional feminino, no Brasil, 42.000 mulheres encarceradas e que representaria um aumento de 656\% em relação ao mesmo número do ano de 2000, quando o número era inferior a 6.000 mulheres detidas. Esse percentual de aumento é praticamente o dobro do aumento, para o mesmo período, em relação à população carcerária masculina, que saltou de 169.000 para 665.000 homens encarcerados. 
E no que se refere à taxa de encarceramento, que era de 6,5 mulheres presas para cada grupo de 100.000 habitantes, em 2000, saltou 525\%, ou seja, passando para 40,6 mulheres para o mesmo grupo de 100.000 habitantes, em 2016. Para esse cálculo, segundo o Infopen Mulheres/2016, abrange também o encarceramento de mulheres com idade inferior a 18 anos. Quando essa faixa etária é afastada, a taxa seria de 55,4.

A questão do encarceramento era eminentemente masculino. Isso trouxe para a prisão o problema da adaptação do sistema prisional feminino, porque tendo como base o sistema masculino, não se considerou as peculiaridades relacionadas à realidade feminina. A respeito, afirma Elizabeth Jelin (1994, p. 127) que:

Uma das grandes contribuições do feminismo tem sido a profunda crítica e o desmascaramento dos suportes do paradigma dominante que coloca os homens (ocidentais) como ponto de referência universal, e que transforma as mulheres (e outros) em diferentes ou invisíveis. Ao fazê-lo movimenta-se num espaço contraditório por um lado, a reivindicação por direitos iguais aos dos homens e um tratamento igualitário por outro, $\mathrm{o}$ direito a um tratamento diferenciado e a valorização das especificidades da mulher. Esse e um segundo conflito inevitável entre o princípio da igualdade e o direito a diferença. É importante reconhece-lo pois estimula o debate e a criatividade e ajuda a evitar dogmatismos.

A igualdade conquistada pelas mulheres, muitas vezes alegadas como argumento de defesa por alguns, é criticada, e com razão, pelo fato de as concessões de direitos em benefício de categorias pessoais (feminino, grupos minoritários) estarem calcadas em uma estrutura (masculina) já existente, quando a igualdade se processa verdadeiramente nas relações sociais, o que sobreleva o conceito de gênero.

Elizabeth Jelin (2018) faz uma colocação digna de nota a respeito do público e do privado, dizendo que, dessa forma manifesta-se uma tensão irresolúvel entre o respeito à privacidade e à intimidade, por um lado, e as responsabilidades públicas pelo outro, o que demanda uma redefinição da distinção entre o público, e o privado, e íntimo, distinção que funcionou no plano simbólico e ideológico, mas não na prática; o Estado moderno teve sempre um poder de fiscalização sobre a família. Devido ao reconhecimento social e a indignação moral em relação a violência doméstica nos últimos anos, nas estratégias atuais de luta, o respeito à privacidade transformase numa necessidade de intervenção quando são violados os direitos humanos nesse âmbito privado já que o respeito à privacidade dentro do contexto familiar não pode justificar a impunidade legal para a violência contra a mulher.

Essa ideia foi aqui colocada para salientar a forma utilizada por uma classe social (classe dominante) para invisibilizar determinados problemas correntes na sociedade com a finalidade de manter uma situação de violência, de discriminação, de desequilíbrio, de assimetria. Era a aplicação do termo popular de que em "briga entre marido e mulher não se mete a colher". A invisibilidade é uma forma de manter o status de uma situação. É o que ocorre com as prisioneiras. 


\section{Os Direitos Humanos das mulheres}

Pode-se dizer que o século passado, com a Declaração Universal dos Direitos Humanos (DUDH), de 1948, foi o marco básico para ações concretas (Jelin, 1993) do início da afirmação dos Direitos Humanos em todo o mundo. No que se refere aos Direitos das Mulheres, Tratados e Convenções internacionais passaram a ser assinados, influenciando a legislação interna dos países, como aconteceu com o Brasil.

A Convenção para Eliminação de Todas as Formas de Discriminação contra as Mulheres - CEDAW (1979) foi o primeiro e mais importante ato internacional em defesa da igualdade com o homem e fim da violência e discriminação contra as mulheres. Mas os movimentos feministas brasileiros não estiveram alheios aos debates. Articulações internas desses movimentos culminaram com a assinatura e ratificação de acordos e tratados internacionais e o reconhecimento e a inserção de vários dispositivos na Constituição Federal de 1988 (PASINATO, 2014, p. 408).

Além da CEDAW (1979), o Brasil é signatário da Convenção Interamericana para Prevenir, Punir e Erradicar a Violência contra a Mulher (Convenção de Belém do Pará, de 1994), das Conferências Internacionais de Direitos Humanos (Viena, 1993), População (Cairo, 1994), Mulheres (Beijing, 1995).

Não se pode descurar também das Regras das Nações Unidas para o tratamento de mulheres presas e medidas não privativas de liberdade para mulheres infratoras, denominadas de Regras de Bangkok. Esses atos internacionais alçaram ao patamar de Direitos Humanos quaisquer formas de discriminação e violência impingidas contra as mulheres, reconhecendo-as como sujeitos de direito (PASINATO, 2014, p. 414). Significa dizer que os Estados partes devem implementar ações positivas e materiais para erradicar qualquer forma de discriminação e desigualdades em desfavor das mulheres, dando a elas proteção qualificada, efetiva e integral. A Constituição Federal de 1988 é tida, internamente, como o marco inicial do avanço formal de reconhecimento de vários direitos de cidadania em benefício das mulheres (PASINATO, 2014, 408).

Ao ser promulgada, automaticamente foi revogada a reserva que o Brasil fazia ao Capítulo sobre família na CEDAW, por isso, ao assinar um convênio, por exemplo, o fará com restrições nas cláusulas que não coadunem com sua legislação. O Brasil, por exemplo, assinou em 1982 a Convenção Contra todas as Formas de Discriminação contra a Mulher, com reservas no capítulo família, pois em nosso Código Civil se atribuía ao homem a chefia da sociedade matrimonial. A nova Constituição de 1988, na qual os movimentos e Conselhos de Mulheres tiveram um papel fundamental, estabelece igualdade entre homens e mulheres na sociedade matrimonial (artigo 226, parágrafo 5) com a qual o governo revogou suas reservas.

Apesar de todos os avanços formais obtidos com a Constituição Federal, "há uma grande lacuna entre os direitos formais e os direitos de fato, excluindo largas parcelas da população feminina" (PASINATO, 2014, p. 
408). Na mesma linha de pensamento, Jacqueline Pitanguy afirma:

A distância entre leis e realidade só poderá diminuir através da ação política. Daí a importância de que órgãos de Governo como a Secretaria de Políticas para as Mulheres (SPM) da Presidência da República trabalhem em articulação com outros órgãos do governo na implementação dos Planos Nacionais de políticas para as Mulheres, e que a sociedade civil organizada continue a desenvolver ações de fortalecimento das mulheres, de advocacy pelos seus direitos, de monitoramento crítico das políticas públicas e da atuação dos legisladores e do judiciário.

Organizações não governamentais que lutam pelos direitos humanos das mulheres em diferentes frentes e Fundos, como o Fundo Brasil de Direitos Humanos, que apoiam essas organizações, contribuem para aproximar o plano normativo da vida real, tornando os direitos humanos das mulheres parte de seu cotidiano na família, no trabalho, na política, em sua vida reprodutiva e sexual, dentre outras dimensões.

Sobre o resultado da pesquisa feita por Wânia Pasinato (2014, p. 424), envolvendo cinco capitais do Brasil, apesar das realidades diversificadas, conclui que as dificuldades foram bastante comuns. Resumindo, são exemplos: falta de investimento público; falta de formação especializada de recursos humanos; falta de qualificação especializada dos profissionais, que conheça e compreenda as especificidades da violência contra as mulheres; falta de protocolos para o atendimento e os encaminhamentos dos casos envolvendo violência de gênero.

\section{A violência contra as mulheres no Brasil: quando o poder está no achatamento da realidade na tradução dos fatos para o processo}

As informações que se seguem foram divulgadas Conselho Nacional de Justiça - CNJ, em 25 de outubro de 2017. São dados do Poder Judiciário sobre a violência contra a mulher, frutos da Portaria do CNJ n. 15, de 08 de março de 2017, que instituiu a Política Judiciária Nacional de Enfrentamento à Violência contra as Mulheres. Essa Portaria estabelece diretrizes e ações para prevenir a violência contra mulheres, conferindo a elas uma adequada solução de conflitos, seguindo as diretrizes da Lei Maria da Penha.

Não se pode descuidar que a própria Lei Maria da Penha (Lei n. 11.340/2006), em seus arts. $3^{\circ}$, $\$ 1{ }^{\circ}$ e 38 , estabeleceu a obrigatoriedade dos órgãos oficiais do Sistema de Justiça e Segurança da formação desse banco de dados sobre a violência contra as mulheres ${ }^{3}$.

Segundo o Conselho Nacional de Justiça, até o final de 2017, existia um processo judicial de violência doméstica para cada grupo de 100 mulheres brasileiras. $\mathrm{O}$ total de processos referentes à violência doméstica

\footnotetext{
${ }^{3}$ Art. 38. As estatísticas sobre a violência doméstica e familiar contra a mulher serão incluídas nas bases de dados dos órgãos oficiais do Sistema de Justiça e Segurança a fim de subsidiar o sistema nacional de dados e informações relativo às mulheres.

Parágrafo único. As Secretarias de Segurança Pública dos Estados e do Distrito Federal poderão remeter suas informações criminais para a base de dados do Ministério da Justiça.
} 
contra a mulher em tramitação na Justiça dos Estados era de 1.273.398. Desses processos, pelo menos 13.500 são casos de feminicído.

Além dessa problemática exposta pelo Conselho Nacional de Justiça, temos outros relatados por Wânia Pasinato e Theóphilos Rifiotis (2007), ou seja, a falta de uniformidade na interpretação da Lei Maria da Penha entre os próprios operadores do direito, e na obliteração, "perda da lembrança", ou o achatamento da realidade na tradução dos fatos para o processo. Significa dizer que a complexidade dos fatos vividos pelas vítimas não foi traduzida para o interior do processo. Talvez, uma impossibilidade das circunstâncias e detalhes da violência vividas por essas mulheres-vítimas não serem traduzidas em palavras escritas, aumentando o descompasso entre a forma e a realidade.

A respeito da litigiosidade, no estado de Rondônia, foram apurados, no ano de 2017, 2.358 novos inquéritos policiais, sendo que havia em tramitação 2.206 inquéritos, e teriam sidos arquivados 1.425 . O total de inquéritos instaurados no mesmo ano, nacionalmente, foi de 290.423 inquéritos, havia 409.327 em andamento, e arquivados 208.901 inquéritos. O próprio Conselho Nacional de Justiça informa que esse número não é exato pelo fato de alguns Estados da Federação não terem encaminhado informações relativas aos processos afetos à violência contra a mulher.

$\mathrm{O} \mathrm{CNJ}$ salienta que esses dados coletados não significam propriamente um diagnóstico da violência contra as mulheres, mas a busca pelas Instituições de Justiça e Segurança por essas mulheres para resolver seus problemas. Informa que, no ano de 2016, foram expedidas 195.038 (cento e noventa e cinco mil e trinta e oito) medidas protetivas pela justiça brasileira. No caso específico deste estado de Rondônia foram expedidas, para aquele mesmo ano, 333 medidas.

A violência contra as mulheres, violência familiar e intrafamiliar, no art. $5^{\circ}$, da Lei n. 11.340/2006 ${ }^{4}$, cuida de estabelecer o que se deve entender por violência doméstica e familiar. No inciso I, trata de definir o âmbito doméstico, ou seja, o espaço de convívio permanente de pessoas, parentes ou não, incluindo-se os agregados, os empregados domésticos. Exemplo destes são os amigos que residem juntos. Aqui o conceito de âmbito doméstico não deve ser compreendido como um lugar apenas, mas pode ser vários locais, como por exemplo, um casal com seus filhos podem frequentar diariamente a casa dos avós que se situam em outro lugar. No inciso II, fala-se do vínculo familiar de parentesco, seja por consanguinidade (natural), por afinidade ou por adoção (por vontade),

\footnotetext{
${ }^{4}$ BRASIL. Lei Maria da Penha. Art. 50. Para os efeitos desta Lei, configura violência doméstica e familiar contra a mulher qualquer ação ou omissão baseada no gênero que lhe cause morte, lesão, sofrimento físico, sexual ou psicológico e dano moral ou patrimonial: I - no âmbito da unidade doméstica, compreendida como o espaço de convívio permanente de pessoas, com ou sem vínculo familiar, inclusive as esporadicamente agregadas; II - no âmbito da família, compreendida como a comunidade formada por indivíduos que são ou se consideram aparentados, unidos por laços naturais, por afinidade ou por vontade expressa;

III - em qualquer relação íntima de afeto, na qual o agressor conviva ou tenha convivido com a ofendida, independentemente de coabitação. Parágrafo único. As relações pessoais enunciadas neste artigo independem de orientação sexual.
} 
podendo ser ou não pertencente ao mesmo âmbito doméstico. No primeiro caso, cuida-se da violência intrafamiliar. Por fim, no inciso III, a lei trata da relação íntima de afeto que envolve o agressor e a vítima, independentemente de coabitação. A hipótese que se encaixa neste caso são os ex-namorados, por exemplo. Nesse aspecto, o Superior Tribunal de Justiça- STJ, que entendia que a relação de ex-namorados não caracterizava violência doméstica, mudou seu entendimento a partir do Conflito de Competência no 103.813 - MG $(2009 / 0038310-8)$

\section{A VIOLENCIA SOB A FORMA DOS ARRANJOS SINTAGMÁTICOS DA VERGONHA E DO MEDO}

A Lei Maria da Penha, em diversos dispositivos, não trata sobre a mulher vítima de violência, mas de mulher "em situação de violência". Esta forma de tratamento é de suma importância, por ampliar as formas de violência descritas no art. 7º, da Lei Maria da Penha. Esse artigo dispõe que:

Art. 70. São formas de violência doméstica e familiar contra a mulher, entre outras:

I - a violência física, entendida como qualquer conduta que ofenda sua integridade ou saúde corporal;

II - a violência psicológica, entendida como qualquer conduta que lhe cause dano emocional e diminuição da autoestima ou que lhe prejudique e perturbe o pleno desenvolvimento ou que vise degradar ou controlar suas ações, comportamentos, crenças e decisões, mediante ameaça, constrangimento, humilhação, manipulação, isolamento, vigilância constante, perseguição contumaz, insulto, chantagem, ridicularização, exploração e limitação do direito de ir e vir ou qualquer outro meio que lhe cause prejuízo à saúde psicológica e à autodeterminação;

III - a violência sexual, entendida como qualquer conduta que a constranja a presenciar, a manter ou a participar de relação sexual não desejada, mediante intimidação, ameaça, coação ou uso da força; que a induza a comercializar ou a utilizar, de qualquer modo, a sua sexualidade, que a impeça de usar qualquer método contraceptivo ou que a force ao matrimônio, à gravidez, ao aborto ou à prostituição, mediante coação, chantagem, suborno ou manipulação; ou que limite ou anule o exercício de seus direitos sexuais e reprodutivos; IV - a violência patrimonial, entendida como qualquer conduta que configure retenção, subtração, destruição parcial ou total de seus objetos, instrumentos de trabalho, documentos pessoais, bens, valores e direitos ou recursos econômicos, incluindo os destinados a satisfazer suas necessidades;

$\mathrm{V}$ - a violência moral, entendida como qualquer conduta que configure calúnia, difamação ou injúria.

Esse dispositivo trata de cinco modalidades de violência que podem ser praticadas contra as mulheres. Mas, a expressão utilizada pela Lei n. 11.340/2006 "em situação de violência" inclui outros aspectos da violência como as questões culturais que não se enquadram nesse conceito, como ocorre com o patriarcado, fator cultural que impõe a dominação masculina e a subordinação feminina no âmbito doméstico. Nesse aspecto salienta Renata Alves da Silva que: 
As pesquisas sobre relações de gênero permitiram dar visibilidade às mulheres e problematizar os padrões pré-estabelecidos nas construções sociais e culturais, com bases no sistema patriarcal, que centraliza o poder nas mãos dos homens. Nessas construções são observados casos de culpabilização da mulher pela agressão sofrida por parte de seus companheiros, transferindo para as vítimas as responsabilidades que neste caso, pertence aos algozes. [...]

O patriarcado surge como uma categoria de análise nesta pesquisa, tanto para demostrar as construções sociais que tendem a definir os papéis sociais e os controles dos corpos femininos, quanto diante da superioridade masculina que minimiza a mulher no mundo privado e doméstico (SILVA, 2016).

Ao abordar a questão de gênero, Renata Alves da Silva (2016) faz uma articulação com o poder como instrumento de dominação da mulher no sistema patriarcal brasileiro, que a coloca numa situação de violência oculta, prioriza e centraliza a função masculina em detrimento da mulher, estabelecendo desigualdades, assimetrias como sendo "naturais". E o fator medo passa a ser uma constante para a estabilidade dessa situação, que impossibilita a tomada de decisão pela mulher, neutralizando qualquer ação que possa descontruir o sistema.

De acordo com Chauí (1987) em ensaio sobre o medo, o sentimento de medo e seu conceito enquanto categoria, é importante para o contexto. Pergunta a filósofa? “- Mas, afinal, do que temos medo? ”. Para Chauí, pode-se ter medo "do grito e do silêncio; do vazio e do infinito; do efêmero e do definitivo; do sempre e do nunca mais".

Também temos medo da "delação e da tortura, da traição e da censura", "da culpa e do castigo; do perigo e da covardia; do que fizemos e do que deixamos de fazer; dos medrosos e dos sem medo", "do esquecimento e de jamais poder deslembrar. Da insônia e de não mais despertar. Do irreparável. Do inominável e do horror à perda do nome próprio". Temos medo "do ódio que devora e da cólera que corrói, mas também da resignação sem esperança, da dor sem fim e da desonra. Da mutilação dos corpos e dos espíritos", da loucura, dos vivos e dos mortos. "Temos medo da fala mansa do inimigo, mas muito mais, quão mais, do inesperado punhal a saltar na mão há pouco amiga para trespassar nosso aberto peito ou pelas costas nos aniquilar." (CHAUÍ, 1987, p. 36-39).

Por isso pode-se ter medo, também, de ser mulher. Nessa perspectiva surge a questão de gênero para a discussão. Mas o que é gênero ou relações de gênero? Maria Zelma de Araújo Madeira e Renata Gomes da Costa (2012, p. 80) afirmam tratar-se, não de "gênero", mas de "relações de gênero" que é um conceito em disputa, em construção. E continuam dizendo, com respaldo em Joan Scott, que o conceito de gênero surge no momento em que as feministas contemporâneas "consideravam as teorias existentes para explicar as desigualdades entre homens e mulheres como insuficientes para definir a desigualdade". O conceito relacional de gênero é qualificado pelo aspecto histórico, cultural, social e pelo poder. Portanto, é dialético, contraditório, variável no curso do tempo:

[...] Diante dessa premissa se compreende que o machismo não é um atributo masculino, perpassando, assim, por toda a sociedade.

As relações de gênero constroem e estruturam papeis e funções do que é ser homem e do que é ser mulher em uma mesma sociedade, historicamente esses papeis construíram e fomentaram relações desiguais, quando se deposita valor numa suposta superioridade 
masculina e numa suposta inferioridade feminina, sobressaindo a violência de gênero.

\section{"E a realidade não é nem um pouco cor-de-rosa"}

A violência contra mulher é determinada por aspectos sociais e culturais que definem e legitimam lugares, direitos, deveres e papéis diferenciados para mulheres e homens, embasando a desigualdade de gênero presente historicamente na sociedade contemporânea. (MADEIRA; COSTA, 2012, p. 86-7) (grifos das autoras).

A violência de gênero pode ocorrer nas diversas esferas das relações sociais, portanto, abrange a violência doméstica, familiar, intrafamiliar e as decorrentes das relações de afeto, ultrapassando os ambientes públicos e privados, podendo ocorrer entre homem contra mulher, homem contra homem e mulher contra mulher.

Acrescente-se a essa situação, os casos em que as vítimas acabam mantendo-se em silêncio sobre as situações de violência em virtude do acometimento do sentimento da vergonha. Neste sentido, esse querer não ser vista "aspectualiza” as qualificações de situação de inferioridade organizada sob a forma do arranjo sintagmático: a vergonha. Segundo Norbert Elias (1993, p. 242):

Não menos característico de um processo civilizador que a racionalização é a peculiar modelação da economia das pulsões que conhecemos pelo nome de vergonha [...] O sentimento de vergonha é uma exaltação específica, uma espécie de ansiedade que automaticamente se reproduz na pessoa em certas ocasiões, por força do hábito. Considerado superficialmente, é um medo de degradação social ou, em termos mais gerais, de gestos de superioridade de outras pessoas. Mas é uma forma de desagrado ou medo que surge caracteristicamente nas ocasiões em que a pessoa que receia cair em uma situação de inferioridade não pode evitar esse perigo nem por meios físicos diretos nem por qualquer forma de ataque. Essa impotência ante a superioridade dos outros, essa total fragilidade diante deles, não surgem diretamente da ameaça de superioridade física que os demais realmente representem - embora-, sem dúvida, tenha suas origens numa composição física, na inferioridade corporal da criança frente aos pais e mestres, por exemplo.

Nesse contexto, encontra-se o sistema patriarcal marcante na sociedade brasileira. É outra e complexa forma de dominação, hierarquizada, centralizada no homem, com nítido desnivelamento entre os membros da família e a ele favorável. Por ser cultural, encontra-se arraigada na consciência social e nos membros da família, e várias barreiras se apresentam em desfavor das mulheres. O exercício do poder serve para a manutenção e sustentabilidade desse sistema e qualquer tentativa que possa gerar instabilidade é reprimida, ou ainda ampliar o sentimento da vergonha. No adulto a impotência advinda do ato da repressão, somada à vergonha, resulta do fato de que as pessoas, cuja superioridade se teme, estão de acordo com o próprio superego da pessoa "com a agência de autolimitação implantada no indivíduo por outros de quem ele depende, que exerciam poder e possuíam superioridade sobre ele" (ELIAS, 1993, p. 242-243).

De conformidade com isso, a ansiedade que denominamos de "vergonha" é profundamente velada à vista dos outros. Por forte que seja, nunca é expressada em gestos violentos. A vergonha tira sua coloração específica do fato de que a pessoa que a sente fez ou está ligada de uma forma ou de outra, e consigo mesma, com o setor de sua consciência mediante o qual controla a si mesma.

\footnotetext{
${ }^{5}$ Trecho retirado da música Rosas da Atitude Feminina (informação das autoras).
} 
E mais, aponta Elias (1993), "o conflito expressado no par vergonha-medo não é apenas um choque do indivíduo com a opinião social prevalecente: seu próprio comportamento colocou-o em conflito com a parte de si mesmo que representa essa opinião". É um conflito dentro de sua própria personalidade. Ele mesmo se reconhece como inferior.

Nesse diapasão, há uma intima ligação entre as relações de gênero e o poder. E o que se compreende por poder? Ou seria influência o melhor termo? Ricardo Mendonça e Sônia Maria Rodrigues Calado Dias (2006), em um artigo intitulado "De French e Raven (1959) ao modelo poder/interação de influência interpessoal: uma discussão sobre poder e influência social" afirmam, de modo sucinto, que poder é a influência potencial, enquanto influência significa o poder em ação, que afeta o comportamento do outro. E dizem que:

O poder forma a base para a habilidade que indivíduos ou grupos têm para influenciar ou mudar o comportamento dos outros. O poder também pode ser visto como o potencial que um indivíduo tem de influenciar o comportamento de outras pessoas ou de resistir às tentativas de influência por parte dos outros.

O poder na definição de Mendonça e Dias (2006) não deixa de ter o caráter relacional, situacional e potencialmente recíproco. Nesse aspecto, os autores trazem uma citação dos psicólogos sociais French e Raven (1959) que é digno de nota fazer menção:

O conceito de poder tem a propriedade conceitual de potencialidade; mas parece útil restringir essa influência potencial a relações de poder mais duradouras entre $\mathrm{O}$ e $\mathrm{P}$, excluindo da definição de poder esses casos onde a influência potencial é tão momentânea ou tão mutável que não pode ser antecipada na relação existente. Poder é um conceito útil para descrever estrutura social apenas se tiver uma certa estabilidade no decorrer do tempo; é inútil se todo estímulo social momentâneo for visto como poder social real.

Se influência é o poder em ação, citam esses autores três categorias básicas de influenciacão empregadas pelas pessoas: enérgicas, racionais e brandas:

As táticas enérgicas envolvem exigências, elevação da voz e assertividade. As táticas racionais envolvem o uso de lógica e de barganha, no sentido de demonstrar que a submissão ou a realização de um acordo é a melhor solução. Por sua vez, as táticas brandas pressupõem uma postura totalmente diversa das anteriores. Nestas, as pessoas agem de forma nitidamente agradável e lisonjeira, adulando aqueles que pretendem influenciar (MENDONÇA; DIAS, 2006, p. 4).

E detalhando um pouco mais essas três categorias, pontuam as estratégias enérgicas. "As estratégias enérgicas são meios através dos quais o agente espera que suas demandas sejam atendidas. Esses meios podem ser tanto solicitações diretas e assertivas de obediência quanto solicitações intermediadas e manipulativas, como ameaças e agressões [...]”. (MENDONÇA; DIAS, 2006, p. 4). As estratégias racionais, por outro lado, envolvem a utilização de barganha e de lógica, consistindo no apelo ou na tentativa de obter um raciocínio instrumental por parte do alvo.

[...] as táticas brandas enfatizam que elas incluem, pelo menos, dois aspectos fundamentais: $\mathrm{o}$ primeiro refere-se ao conteúdo do que é dito e o segundo à forma ou ao modo de dizer. Tanto "o quê" uma pessoa diz quanto o "como" ela diz algo buscam, em essência, influenciar 
os resultados obtidos. Especificamente, as estratégias brandas são utilizadas quando o agente busca obediência de uma maneira cortês, amigável ou humilde, demonstrando simpatia com o alvo da influência. Essas estratégias envolvem um meio de influência menos agressivo e mais psicológico, sendo projetadas para assegurar a obediência pela própria vontade do alvo [...]. (MENDONÇA; DIAS, 2006, p. 3-4)

Renata Alves da Silva (2016), ao se referir ao sistema patriarcal, citou o fator medo como componente da estabilidade, que impossibilita, neutraliza qualquer ação que possa desconstruí-lo.

Ainda a respeito do medo, Marilena Chauí (1987), citando Josep Ramoneda (Depois da paixão política), em seu artigo sobre o fundamentalismo religioso, afirma que: "no Ocidente houve um empenho para construir um novo inimigo, porque o medo é sempre uma ajuda para o governante”. O inimigo é o Outro, o que põe em perigo a própria identidade, seja a ameaça real ou induzida. $\mathrm{O}$ temor ao Outro favorece a coesão nacional em torno do poder e faz com que a cidadania seja menos exigente com os que governam, que são também os que a protegem, nos termos de Chauí (1987).

Essa situação sobre o medo pode ser perfeitamente transplantada não somente para a realidade patriarcal, mas também como para a violência nas relações de gênero, tal como é a proposta na presente discussão.

\section{A LEI MARIA DA PENHA NO CONTEXTO DO ESTUDO: DA MOTIVAÇÃO DA LEI AO DIREITO DA MULHER}

A Lei n. 11.340/2006 é o resultado da luta de Maria da Penha Maia Fernandes que expôs o seu caso perante a Comissão Interamericana de Direitos Humanos, órgão da Organização dos Estados Americanos (OEA), com sede em Washington, Estados Unidos.

Conforme apresenta Rogério Sanches Cunha e Ronaldo Batista Pinto (2007, p. 11):

O motivo que levou a lei a ser "batizada" com esse nome, pelo qual, irreversivelmente, passará a ser conhecida, remonta ao ano de 1983. No dia 29 de maio desse ano, na cidade de Fortaleza, no Estado do Ceará, a farmacêutica Maria da Penha Maia Fernandes, enquanto dormia, foi atingida por tiro de espingarda desferido por seu então marido, o economista Marco Antônio Heredia Viveiros, colombiano de origem e naturalizado brasileiro. Em razão desse tiro, que atingiu a vítima em sua coluna, destruindo a terceira e a quarta vértebras, suportou lesões que a deixaram paraplégica.

Foi o desfecho de uma relação tumultuada, pontilhada por agressões perpetradas pelo marido contra a esposa e também contra as filhas do casal. Homem de temperamento violento, sua agressividade impedia a vítima, por temor, de deflagrar qualquer iniciativa visando a separação do casal, de passado obscuro, descobriu-se, depois, que já se envolvera na prática de delitos e que possuía um filho na Colômbia, fato ignorado pela ofendida.

Seu caso foi apresentado por ela própria perante a Corte, bem como também pelo CEJIL - Centro pela Justiça e o Direito Internacional e CLADEM - Comitê Latino-Americano e do Caribe para a Defesa dos Direitos da Mulher, recebido em 20 de agosto de 1998 (CUNHA e PINTO, 2007, p. 13). 
Em resposta, a Comissão, após análise, por ter havido violação de direitos humanos, publicou o Relatório n. 54, em 16 de abril de $2001^{6}$ recomendando ao Brasil (caso 12.051):

1. Completar rápida e efetivamente o processamento penal do responsável da agressão e tentativa de homicídio em prejuízo da Senhora Maria da Penha Fernandes Maia.

2. Proceder a uma investigação séria, imparcial e exaustiva a fim de determinar a responsabilidade pelas irregularidades $\mathrm{e}$ atrasos injustificados que impediram o processamento rápido e efetivo do responsável, bem como tomar as medidas administrativas, legislativas e judiciárias correspondentes.

3. Adotar, sem prejuízo das ações que possam ser instauradas contra o responsável civil da agressão, as medidas necessárias para que o Estado assegure à vítima adequada reparação simbólica e material pelas violações aqui estabelecidas, particularmente por sua falha em oferecer um recurso rápido e efetivo; por manter o caso na impunidade por mais de quinze anos; e por impedir com esse atraso a possibilidade oportuna de ação de reparação e indenização civil.

4. Prosseguir e intensificar o processo de reforma que evite a tolerância estatal e o tratamento discriminatório com respeito à violência doméstica contra mulheres no Brasil. A Comissão recomenda particularmente o seguinte:

a) Medidas de capacitação e sensibilização dos funcionários judiciais e policiais especializados para que compreendam a importância de não tolerar a violência doméstica;

b) Simplificar os procedimentos judiciais penais a fim de que possa ser reduzido o tempo processual, sem afetar os direitos e garantias de devido processo;

c) O estabelecimento de formas alternativas às judiciais, rápidas e efetivas de solução de conflitos intrafamiliares, bem como de sensibilização com respeito à sua gravidade e às consequências penais que gera;

d) Multiplicar o número de delegacias policiais especiais para a defesa dos direitos da mulher e dotá-las dos recursos especiais necessários à efetiva tramitação e investigação de todas as denúncias de violência doméstica, bem como prestar apoio ao Ministério Público na preparação de seus informes judiciais.

e) Incluir em seus planos pedagógicos unidades curriculares destinadas à compreensão da importância do respeito à mulher e a seus direitos reconhecidos na Convenção de Belém do Pará, bem como ao manejo dos conflitos intrafamiliares.

5. Apresentar à Comissão Interamericana de Direitos Humanos, dentro do prazo de 60 dias a partir da transmissão deste relatório ao Estado, um relatório sobre o cumprimento destas recomendações para os efeitos previstos no artigo 51(1) da Convenção Americana.

ários entraves surgiram no início da aplicação da Lei n. 11.340/2006. Houve arguição de sua inconstitucionalidade, por tratar diferentemente homens e mulheres, e questionamentos específicos a respeito da necessidade de representação ou não da vítima nos casos de lesão corporal praticado pelo autor da agressão.

A inconstitucionalidade foi afastada, e no que se refere à necessidade ou não de representação da vítima, na Ação Direta de Inconstitucionalidade - ADI n. 4424/DF, julgada pelo Supremo Tribunal Federal (STF) em 2012, definiu-se que em relação às lesões corporais resultantes de violência doméstica contra mulheres a ação penal seria pública incondicionada, ao contrário de outras situações semelhantes em que ocorra também lesão corporal, quando a manifestação do ofendido é necessária para que a autoridade policial instaure o inquérito policial e o Ministério Público Federal (MPF) ofereça a ação penal contra o infrator. Com essa decisão do

\footnotetext{
${ }^{6} \mathrm{O}$ relatório encontra disponível em: https://cidh.oas.org/annualrep/2000port/12051.htm.
} 
Supremo Tribunal, retirou-se a possibilidade de a vítima afastar o inquérito ou o ajuizamento da ação penal.

Em razão da sua natureza interdisciplinar e não se destinar apenas aos juristas, viu-se na necessidade de fazer uma breve abordagem do que se deve entender por crime (ou delito) e pena.

Em qualquer sociedade é possível identificar uma estrutura de poder que lhe proporcione certa estabilidade, valendo-se de mecanismos institucionalizados ou não (de métodos difusos), com grupos que dominam e outros que são dominados, com emprego de meios mais ou menos sutis, encobertos ou explícitos de controle social em maior ou menor grau de centralização. "O controle social seria a influência da sociedade que delimita o âmbito da conduta do indivíduo" (ZAFFARONI; PIERANGELI, 1997, p. 60-61).

Nessa linha de raciocínio, temos o Direito e, em especial, o sistema penal, que exerce um controle social institucionalizado e explícito. Mas, o campo do controle social é muito mais amplo e complexo. Segundo Zaffaroni e Pierangeli (1997, p. 62):

Uma sociedade é mais ou menos autoritária ou mais ou menos democrática, segundo se oriente em um ou outro sentido a totalidade do fenômeno e não unicamente a parte do controle social institucionalizado ou explícito.

Assim, para avaliar o controle social em um determinado contexto, o observador não deve deter-se no sistema penal, e menos ainda na mera letra da lei penal, mas é mister analisar a estrutura familiar (autoritária ou não), a educação (a escola, os métodos pedagógicos, o controle ideológico dos textos, a universidade, a liberdade de cátedra etc.), a medicina (a orientação "anestesiante" ou puramente organicista, ou mais antropológica de sua ideologia e prática) e muitos outros aspectos que tornam complicadíssimo o tecido social. Quem quiser formar uma ideia do modelo de sociedade com que depara, esquecendo esta pluridimensionalidade do fenômeno de controle, cairá em um simplismo ilusório (itálico dos autores).

O Estado de Direito brasileiro é do tipo federativo, republicano e tem como primado a lei (art. $1^{\circ}$, da Constituição Federal). A lei é um instrumento de controle social. Ela também estrutura o poder e tutela bens, valores e interesses que a sociedade (classe dominante) elege como prioritários, como os mais importantes. E a lei penal justamente tutela esses bens valorados, cominando sanções ao agente que, com sua conduta, transgride a regra estabelecida. É para isso que se presta a lei penal, o Direito Penal, entendido este como, na definição de Noronha (2009), fazendo menção a Von Liszt: o "conjunto das prescrições emanadas do Estado, que ligam ao crime, como fato, a pena como consequência".

As pessoas praticam continuamente ações, ou deixam de praticar condutas devidas a todo momento, e no mesmo instante em que as praticam, esses acontecimentos se tornam fatos da vida real. Dizer que fato é um acontecimento passado é um pleonasmo, porque todo fato é pretérito. E a maioria desses fatos pode ter sua relevância para o sujeito como necessário para o seu desenvolvimento e crescimento, mas para o direito, são considerados muitas vezes irrelevantes. O fato quando tem relevância na esfera jurídica do sujeito diz-se que se trata de um fato jurídico, e quando decorre de uma conduta humana diz-se ato jurídico. O conceito de fato é mais 
abrangente na medida em que envolve também acontecimentos que não resultam de uma ação humana, como por exemplo a morte natural de uma pessoa.

A sociedade se vale da lei como instrumento para regular os fatos, atos, acontecimentos ou omissões que julga importante para uma convivência pacífica entre os seres humanos.

O Direito como um todo constitui-se em um sistema de controle e uma faceta de todo esse arcabouço da estrutura de poder, do controle social. E o Direito Penal, por sua vez, ocupa-se de uma pequena parcela desse sistema, mas muito importante para o mundo jurídico penal.

A imposição de uma pena a um determinado sujeito que pratica uma conduta ilícita não deixa de ser uma violência das mais extremas. A lei penal, em razão disso, deveria ser a ultima ratio para a sociedade exercer o controle social. Daí a necessidade de ser ela institucionalizada, para estabelecer um mínimo de garantias, definindo o que seja crime, com minúcias, e a pena aplicável na hipótese de violação da norma.

O Princípio da legalidade e da anterioridade é o resultado de uma conquista social histórica de todos os povos e representa a garantia de todos, brasileiros ou não, de que ninguém será punido por crime sem uma lei anterior que o defina, e nem estar sujeito a uma pena sem que haja prévia cominação legal. Esse princípio está previsto na Constituição Federal de 1988 (art. 5o, inciso XXXIX), no Código Penal (art. 1º), e em Tratados Internacionais como no Pacto de San José de Costa Rica - 1969 (artigo 19) e no Pacto Internacional sobre Direitos Civis e Políticos (Decreto 593/92). Na legislação penal existem as chamadas contravenções penais, disciplinadas no Decreto-lei no 3.688/1941, que cominam pena de prisão simples ou multa aos infratores. As contravenções possuem características próprias que as diferenciam dos crimes ou delitos. Elas são consideradas infrações de menor potencial ofensivo, não se pune a tentativa, não possuindo extraterritorialidade, restritas às contravenções praticadas no país, cuja pena de prisão é cumprida no regime semiaberto ou aberto, sem rigor penitenciário.

Há, por sua vez, inúmeras leis que tratam dos crimes ou delitos. O principal é o Código Penal (Decretolei no 2.848/1940). Mas, leis especiais também definem as infrações penais, como a Lei n. 11.343/2006 (Lei antidrogas), o Estatuto da Criança e do Adolescente, o Estatuto do Idoso, a Lei de Falência e Recuperação de Empresas, a Lei do Desarmamento, o Código Eleitoral, a Lei de Tortura, etc.

O conceito de crime e contravenção no país é legal, definido no art. 10, da Lei de Introdução ao Código Penal (Decreto-lei n. 3.914/1941):

Considera-se crime a infração penal que a lei comina pena de reclusão ou de detenção, quer isoladamente, quer alternativa ou cumulativamente com a pena de multa; contravenção, a infração penal a que a lei comina, isoladamente, pena de prisão simples ou de multa, ou ambas, alternativa ou cumulativamente.

Apesar de o conceito ser legal, critica-se pela ideia de ser insuficiente e não definir o que seja propriamente crime, pois, apenas descreve a pena aplicável ao caso (Omnis definitio in jure periculosa est). Mas, 
mesmo na doutrina jurídica penal, o conceito de crime sofre pequenas variações na medida em que os elementos essenciais que cada qual entende importante influencia na definição do que seja infração penal. E o enfoque na definição, além do jurídico, formal ou material, pode ser também histórico, sociológico, antropológico, etc., conforme a área de atuação. Na hipótese, priorizamos o conceito jurídico-dogmático de crime proposta por Noronha (2009): "Considera-se, então, o delito como a ação típica, antijurídica e culpável”. O conceito jurídico integra o texto da lei penal com o fato.

A norma penal é a descrição pela lei de determinadas condutas proibidas. Por se tratar da descrição de uma conduta, o elemento nuclear do tipo penal é o verbo que se refere a um comportamento, a uma conduta humana, seja uma ação ou omissão, sujeita a sanção (reclusão, detenção e/ou multa). Todavia, a mera presença do verbo descrevendo uma conduta é insuficiente. Há a necessidade de outros elementos que, agregados ao verbo, integram o chamado tipo penal. Exemplos: Art. 121. Matar alguém. Pena: reclusão de 6 a 20 anos (homicídio); Art. 155. Subtrair, para si ou para outrem, coisa alheia móvel. Pena: reclusão de 1 a 4 anos e multa ${ }^{7}$ (furto). Os verbos que fazem parte dos tipos penais de homicídio e furto, matar e subtrair, estão associados a elementos indispensáveis à definição dos delitos.

Para que exista um crime é necessário a ocorrência de um fato, a prática de uma conduta humana intencional ou culposa (ação ou omissão) que se harmonize com a descrição da norma penal, em todos os seus elementos e circunstâncias. Assim, o primeiro passo para que exista crime é que o fato seja qualificado pelo enquadramento na lei penal. Quando isso acontece, diz-se que houve tipicidade (exemplo: "A" desfere golpe de faca em "B" que vem a óbito). Contudo, isso não basta! É necessário que o fato seja ilícito, ou seja, que contrarie o ordenamento jurídico, ou que estejam ausentes causas permissivas da ação lesiva (exemplo: deferir golpe de faca estando em legítima defesa não seria crime $^{8}$ ), porque o Estado não pode estar presente em todo local e em todo momento para prevenir a ocorrência de um delito, de modo que se permite que as pessoas, elas próprias, possam atuar em defesa de sua pessoa e de seus bens.

É necessário ainda que o agente seja imputável, capaz de ser sancionado com pena criminal (maior de 18 anos e capaz). Um menor de 18 anos, não cometeria crime (comete ato infracional); do mesmo modo, um deficiente mental (inimputável). Exige-se também para a ocorrência de um delito que tenha o sujeito, ao menos potencialmente, a consciência da ilicitude de sua conduta (deve ter a consciência de que desfere golpes de faca em alguém), ou seja, não comete homicídio quem desfere disparos contra uma caixa desconhecendo o fato de uma pessoa estar escondida dentro dela. Por fim, que haja possibilidade (física ou jurídica) de o sujeito praticar outra conduta de modo a evitar o resultado lesivo (livre arbítrio), como no caso de uma mulher obrigada a disparar uma

\footnotetext{
${ }^{7}$ BRASIL. Código Penal Brasileiro (Decreto-lei n. 2.848/1940).

${ }^{8}$ Arts. 23 e 25, ambos do Código Penal.
} 
arma de fogo contra alguém, como condição de resgate de seu filho nas mãos de sequestradores, por exemplo. Nesse caso, não seria crime pelo fato de não haver alternativa possível para essa mãe.

Ainda sobre o crime é preciso estabelecer uma distinção entre as chamadas condutas intencionais (ou dolosas) e culposas. A lei de regra descreve condutas criminosas intencionais, dolosas, e excepcionalmente, estabelece crimes culposos (art. 18, parágrafo único, do Código Penal).

A própria lei penal diz o que seja crime doloso e culposo (art. 18, incisos I e II, do Código Penal). Doloso é aquele praticado intencionalmente, quando o agente deseja o resultado (quer o resultado) ou assume o risco de produzi-lo (o resultado lhe é indiferente, tanto faz ocorrer ou não); culposo quando o agente deu causa ao resultado por imprudência (conduta ativa descuidada), negligência (desatenção no dever de agir, ou não praticar aquilo que está obrigado por falta de atenção) ou imperícia (falta de habilidade técnica).

Os tipos penais estão sempre acompanhados de uma sanção, de uma pena.

Nos termos do art. 32 do Código Penal, as penas são: privativa de liberdade, restritiva de direitos e multa.

As penas privativas de liberdade podem ser de três categorias, de acordo com a gravidade da infração: prisão simples (próprio das contravenções penais), detenção e reclusão9 (respectivamente, da menor para a de maior gravidade). As restritivas de direitos, por sua vez, podem ser, nos termos do art. 43, do Código Penal, prestação pecuniária, perda de bens e valores, prestação de serviços à comunidade ou a entidades públicas; interdição temporária de direitos; limitação de fim de semana.

O legislador não estabelece penas restritivas de direitos nos tipos penais. Apesar da autonomia dessa modalidade de pena, elas são utilizadas em substituição às penas privativas de liberdade aplicadas aos sujeitos que cometem delitos, desde que preenchidos determinados requisitos. E nesse particular, a Lei Penal não permite a substituição quando a infração for cometida mediante violência e grave ameaça a pessoas (art. 44, do Código Penal).

Destaque: sobre esse aspecto tem reflexo importante nas infrações que tratam de violência contra a mulher, apesar do art. 17 da Lei n. 11.340/2006, vedar a aplicação, nos casos de violência doméstica e familiar contra a mulher, somente das penas de cesta básica ou outras de prestação pecuniária, ou que a substituição da pena implique o pagamento isolado de multa. A princípio estaria permitido a substituição por outras modalidades de penas restritivas de direitos. Do mesmo modo que as penas privativas de liberdade são substituídas por penas restritivas de direitos, em caso de descumprimento destas penas, podem ser reconvertidas em prisão, o que não acontece mais com as penas de multa que são consideradas dívidas de valor (art. 51, do Código Penal). Vale lembrar que, não somente o próprio Texto Constitucional proíbe a prisão do devedor por dívidas, como também

\footnotetext{
${ }^{9}$ Art. 10, da Lei de Introdução ao Código Penal.
} 
os Tratados Internacionais sobre Direitos Humanos (art. 70, item 7, do Pacto de San José da Costa Rica; Convenção Americana sobre Direitos Humanos).

O pressuposto para a existência de um crime, além da descrição legal da conduta e da pena em um tipo na lei, necessita ainda de uma conduta humana. Como assinala Prado (2005, p. 314):

O delito só existe enquanto ação humana (Direito Penal do fato) e não como estado, condição social, modo de ser ou atitude (Direito Penal do autor), mormente em uma sociedade livre e democrática, em que vige o primado da lei e do respeito inarredável aos direitos e garantias fundamentais do homem. Ademais, o simples querer ou pensar, sem qualquer exteriorização, sequer pode ser objeto de consideração no campo penal: cogitationis poenam nemo patitur.

Após a prática de um determinado fato que se constate ser crime (tipicidade), pode-se de imediato identificar dois fatores facilmente: o fato e o seu autor. Diante dessa constatação, pontua Toledo (1999, p. 250251):

É possivel, para a construção de um sistema punitivo, tomar-se por base um desses dois fatores (o fato ou o autor), ou ambos ao mesmo tempo. Um sistema que considerasse exclusivamente o fato, destacado do agente, seria um puro "direito penal do fato" (Tatstrafrecht). Outro que, ao contrário, considerasse exclusivamente o autor, destacado do fato, seria puro "direito penal do autor ( Täterstrafrecht).

Embora essa questão sobre direito penal do autor e direito penal do fato já esteja superada na doutrina penalista, essa ideia de punir o autor "pelo o que ele é" e não "pelo o que ele fez" é difusa nos textos de lei. Para exemplificar, ainda se fala em punição das contravenções de mendicância, de vadiagem, de embriaguez, como também o Código Penal coloca à disposição do juiz, no momento de fixação da pena, as condições pessoais do agente, como os maus antecedentes, a conduta social, a personalidade, e a reincidência.

Será que a construção de penitenciárias distantes dos centros urbanos não seria uma forma de manifestação do chamado direito penal do autor? Se tomarmos as manifestações das pessoas nos sites de relacionamentos na internet contra os corruptos, estupradores, ladrões, traficantes, homicidas, não seriam formas sub-reptícias de expressão do direito penal do autor?

O Direito Penal que leva em consideração a característica do sujeito como "ser", e não o "dever ser", é um Direito Penal do Autor. Como afirmam Zaffaroni e Pierangeli (1997, p. 119):

Seja qual for a perspectiva a partir de que se queira fundamentar o direito penal de autor (culpabilidade de autor e periculosidade), o certo é que um direito que reconheça, mas que também respeite, a autonomia moral da pessoa jamais pode penalizar o "ser" de uma pessoa, mas somente o seu agir, já que o direito é uma ordem reguladora de conduta humana. Não se pode penalizar um homem por ser como escolheu ser, sem que isso violente a sua esfera de autodeterminação.

Para os adeptos do direito penal do autor o crime praticado pelo sujeito seria um mero "sintoma de uma personalidade; o proibido e reprovável ou perigoso seria a personalidade e não o ato" (ZAFFARONI; PIERANGELI, 1977, p. 119). Então poderia se dizer que as contribuições da criminologia, da medicina, da 
psiquiatria, da psicologia, da antropologia criminal são inúteis? Na verdade, essas disciplinas têm sua importância dentro de cada área de atuação, no estudo do próprio ser, mas não são normativas.

O problema está em justamente levar em consideração as características de disciplinas que estudam o "ser" para o campo do "dever ser", e utilizar o Direito Penal como forma de controle social e punição do agente pelo que "ele é".

Não se duvida das importantes contribuições da medicina, psiquiatria, psicologia, criminologia, antropologia no estudo do sujeito como autor de delitos. Porém, mesmo que se possa estabelecer uma certa probabilidade de que o agente cometerá novo delito, essa possibilidade não pode ser objeto de punição. Aliás, qualquer pessoa é um sujeito potencial a cometer crimes, de modo que não seria correto afirmar que se trata de fato do criminoso.

O crime e a pena, necessariamente, têm que estar definidos em lei, previamente, em obediência aos princípios da anterioridade e da legalidade. Não se pode punir ninguém por fato anterior a uma lei. Assim, o legislador seleciona dentre as várias condutas que podem ser praticadas na sociedade, aquelas que justamente afetam determinados bens jurídicos que ele entende importante para o bom convício das pessoas, cominando uma sanção.

Para Toledo (1999, p. 79):

O crime, além de fenômeno social, é um episódio social da via de uma pessoa humana. Não pode ser dela destacado e isolado. Não pode ser reproduzida em laboratório, para estudo. Não pode ser decomposto em partes distintas. Nem se apresenta, no mundo da realidade, como puro conceito, de modo sempre idêntico, estereotipado. Cada crime tem a sua história, a sua individualidade; não há dois que possam ser reputados perfeitamente iguais. [...]

Da exposição feita sobre o bem jurídico protegido e das conclusões a que estão se chegou, extrai-se, sem muito esforço, que, substancialmente, o crime é um fato humano que lesa ou expõe a perigo bens jurídicos (jurídico-penalmente) protegidos.

A lei não pode criminalizar o agente em razão de seu modo de ser, a sua personalidade, pois seria inconstitucional (MOHAMED, 2010).

Punir o agente pelo seu modo de ser, por ser o que ele é, e punir o agente em razão de sua conduta por ter praticado um fato definido na lei como crime são dois sistemas distintos que muitas vezes se opõem. Todavia, não se pode desconsiderar o que afirma Francisco de Assis Toledo (1999, p. 251) sobre essa dicotomia:

$\mathrm{Na}$ verdade, porém, nenhum sistema se apresenta com essa pureza. O que há são sistemas que mais se aproximam ora de um, ora de outro desses dois extremos.

[...]

Entre essas duas posições opostas, situam-se as correntes moderadas em prol de um direito penal do fato que considere também o autor. Esta é a posição do direito penal, predominantemente um moderado direito pela do fato. Assim é na Alemanha, na Itália e no Brasil e em outros países civilizados.

Não se nega aqui que existem determinados ambientes sociais que guardam uma alta correlação com 
pessoas que se envolvem em crimes. É o que se pode concluir também da pesquisa que feita para este trabalho, conforme mostram os dados que seguem na seção seguinte. Entretanto, mesmo assim, estar-se-ia fazendo uma análise do agente do fato e não do fato do agente.

\section{PESQUISA DE CAMPO: PENITENCIÁRIA FEMININA DE JI PARANÁ-RO}

Este estudo envolveu entrevistas gravadas e questionário semiestruturado com 64 perguntas (apêndice), com 24 presidiárias, na Penitenciária Feminina de Ji-Paraná, conhecido Presídio Agenor Martins de Carvalho, localizada na zona rural desse município, cujo acesso é feito por via não-asfaltada, na Estrada do Nazaré, km 4,5, distante $370 \mathrm{~km}$ da capital Porto Velho - RO.

A escolha deste presídio se deu em virtude da facilidade de acesso, logística e proximidade com as atividades dos pesquisadores.

O estabelecimento compõe-se de uma área administrativa, logo no portão de entrada, uma área para atendimento médico e outras salas administrativas à frente, e dois pavilhões, separados por um corredor ao centro, com acesso pela lateral esquerda dessa área administrativa ao centro, contendo cada um dos pavilhões aproximadamente 24 detentas, entre condenadas definitivas e presas provisórias. Há ainda, anexo aos pavilhões, mais duas celas, uma destinada às condenadas do semiaberto que não tem acesso externo, e a outra como triagem.

Para o levantamento dos dados visitamos o local em três dias, sendo: 17/12/2017, 14/01/2018 e 21/01/2018. Para quem não conhece a região, são dois meses altamente chuvosos. Praticamente chove todos os dias, tornando a via de acesso um desafio para quem transita com veículo de passeio.

O que motivou a pesquisa foram os dados do Infopen, que em junho de 2016 citava a existência no país de 726.712 pessoas detidas, sendo 42.355 mulheres, representando 5,83\% a população carcerária feminina nacional. No Estado de Rondônia, havia 10.832 pessoas encarceradas nos estabelecimentos prisionais, sendo 721 o número de mulheres, equivalendo a $6,66 \%$ da população carcerária estadual, o que significa dizer que a Justiça de Rondônia prende mais mulheres. A taxa média nacional de aprisionamento, naquele ano, foi de 40,6 pessoas para cada grupo de 100.000 habitantes.

A análise sobre o recorte de gênero no sistema penitenciário rondoniense também teve como fonte de dados os documentos e/ou informações inseridas pela Superintendência no relatório INFOPEN (Levantamento Nacional de Informações Penitenciárias), ligado ao Ministério da Justiça.

Comparando ainda o Brasil com os países que mais encarceram mulheres, em números absolutos, o país se encontra em 4 lugar, sendo superado pelos Estados Unidos da América, China e Rússia; se comparado com a taxa de encarceramento para cada grupo de 100.000 habitantes, o Brasil ocupa a $3^{a}$ posição no ranking mundial, 
perdendo para os Estados Unidos e Tailândia.

Procurando realizar um cruzamento com os dados demográficos do IBGE (2016), essa autarquia havia projetado para Rondônia uma população de 1.787 .279 , para o ano de 2016, o que significa que este Estado possuía uma taxa de encarceramento de 40,34 pessoas detidas para um grupo de 100.000 habitantes.

Dados ainda do Infopen, no período de 2000 a 2016, demonstram que houve um crescimento da massa carcerária feminina de 656\% no Brasil, ao passo que a população carcerária masculina, para o mesmo período, teve um crescimento de $293 \%$. E referindo-se à taxa de encarceramento por grupo de 100.000 , houve, para o período, um crescimento de 525\%, que era de 6,5 mulheres em 2000. Ainda no Infopen Mulheres (2018) aponta que em relação aos demais países do mundo, a taxa é de 455\%. Assim, os dados revelam o modelo punitivo coercitivo, reflexo da reforma penal iniciada desde o século XVIII na Europa e que ainda hoje reorienta o modo de punição no mundo, não diferentemente no Brasil e no estado de Rondônia. Com base em Foucault (2007), neste modelo a prisão é o principal suporte institucional de punição e tem lastro no encarceramento como uma técnica de coerção dos indivíduos, por isso se emprega da forma de controle social dos grupos das camadas populares da sociedade. Para dar conta dessa dinâmica do poder de punir, cresceu o número de instituições prisionais, que, além de isolar os condenados do tecido social, submete os indivíduos punidos com a privação de liberdade por conta de ilegalidades cometidas. Ou ainda, tomando Thompson (1984, p. 6): "punir é castigar, fazer sofrer".

Vale mencionar que no início dos trabalhos, tinha-se como objetivo realizar as entrevistas com as mulheres encarceradas tendo como base as tipificações de infrações penais que elas poderiam estar enquadradas. No entanto, ao depararmos com o perfil das condenadas, a sua maioria estava detida por tráfico de drogas, o que impossibilitou a tipificação inicial, mas não o trabalho de pesquisa. Essa confirmação está presentificada nos dados "Mulheres encarceradas no Brasil", indicando que 64\% das encarceradas estão condenadas pelas seguintes razões: crimes de droga - tráfico de drogas e associação ao tráfico (Infopen, 2014). De acordo com Luiz Flávio Gomes (2011): “a Lei de Drogas e Entorpecentes é a lei específica que mais encarcera mulheres no Brasil, sendo seguida pelo Estatuto do Desarmamento".

Para as análises, importante citar que quatro das entrevistadas não concordaram em gravar a entrevista, de modo que suas declarações foram anotadas somente no questionário. Das demais também foram anotadas na folha do questionário, contudo, não com tanta preocupação dos detalhes, já que o depoimento estava sendo gravado. Essa metodologia serviu-nos para melhor registro dos dados e ao mesmo tempo transmitir a confiabilidade às entrevistadas. Do questionário e entrevista seguem as categorias utilizadas para traçar o perfil das mulheres encarceradas no Presídio Agenor Martins de Carvalho, no município de Ji-Paraná, estado de Rondônia.

Observou-se que $62 \%$ das entrevistadas são nativas do estado de Rondônia. As demais, a sua maioria, são originárias de outros estados da Federação, mas já estavam radicadas no lugar. Uma pequena minoria veio para 
Rondônia, tendo como uma das portas de entrada, especificamente a busca por drogas, o que evidencia uma possível rota do tráfico interestadual. De toda forma, pode-se dizer que o problema prisional feminino é local e tem estreitas relações com o tráfico de drogas. Os dados apontam que $62 \%$ das mulheres encarceradas nasceram em Rondônia e 38\% são de outros Estados. Isso significa de acordo com nossas análises que o estado está falhando em algumas ações, como por exemplo, projetos voltados à educação, ao trabalho e renda, dentre outros, que possam dar condições plenas de vida com dignidade humana para as mulheres que aqui nascem. $\mathrm{O}$ alto número de mulheres rondonienses presas pode ser indicativo para as políticas públicas direcionadas a elas. Isso tem a ver com a Declaração Universal dos Direitos Humanos/DUDH (ONU, 1948), que já estabelece a proteção universal dos direitos humanos, e o Brasil é signatário. Assim, educação, saúde, trabalho, moradia, etc., são considerados direitos humanos, e na Constituição brasileira (1988) evidencia-os enquanto direitos sociais que devem ser respeitados.

Relacionado aos índices acima, do grupo das entrevistadas, mais da metade delas, quatorze (14), num grupo de vinte e quatro (24), são consideradas jovens, estão na faixa etária entre 18 e 29 anos de idade. Os resultados não destoam das informações do Infopen (2014), onde apontam quanto à faixa etária cerca de: "50\% das mulheres encarceradas têm entre 18 e 29 anos; $18 \%$, entre 30 e 34 anos; $21 \%$, entre 35 e 45 anos; $10 \%$ estão na faixa etária entre 46 e 60\%; e 1\%, tem idade entre 61 e 70 anos". A história de vida de infância dessas mulheres é marcada por muita tristeza, sofrimento e horrores, e revela serem frutos de família sem um padrão estrutural. Segundo pesquisas, na mesma direção, esse fator é observado em outros presídios femininos pelo Brasil, conforme aponta Juliana Melo (2016) em estudo realizado com as encarceradas na Penitenciária Feminina do Distrito Federal. A faixa etária das prisioneiras indica que a principal fase produtiva da vida foi perdida dentro do cárcere. Perfil semelhante também encontrou Paula Carvalho Peixoto (2017) entre as reclusas da Penitenciária Feminina do Distrito Federal. A maior representatividade estava na faixa de 20 a 31 anos de idade.

No caso em análise, muitas das encarceradas de Ji-Paraná foram criadas pelo padrasto ou madrasta, avós, tios, parentes, ou somente pelo pai ou pela mãe. A carência afetiva paterna ou materna ficou evidenciada nos discursos das entrevistas, bem como o ódio sustentado contra algum deles, ou outro parente, estranho ao seio familiar por serem elas vítimas da violência, de abusos sexuais, desprezo e abandono por essas pessoas. Aliado a isso, observou a condição de pobreza econômica no seio familiar, pois segundo dados trazidos logo adiante, muitas dessas famílias sobreviviam com menos de um salário mínimo e meio, para alimentar várias pessoas na mesma casa.

O quadro que se seguiu, demonstrou o quantitativo de mulheres que se declararam pardas, brancas e pretas. Quando unificamos os quantitativos de mulheres pardas e pretas, chegamos ao percentual de 83\%, em oposição aos brancos 17\%; o que significa dizer que a massa carcerária feminina é eminentemente de origem 
negra. Comparando esses dados raciais com os do Infopen (2016), a nível nacional, a população carcerária feminina negra era de 62\%, em oposição à população branca (37\%) e amarela (1\%). Não se pode de antemão dizer que a justiça brasileira encarcera mais negras que brancas, porque essa afirmação não poderia estar divorciada dos aspectos ético-raciais da sociedade brasileira, quando se sabe que a maioria é de origem negra. E a respeito dessa problemática, já foi assinalado em estudos sobre a exclusão da pergunta sobre a questão racial, pelo fato de a resposta necessitar de uma interpretação do que se entende por negro, preto e pardo (Estudos do IBGE). Inclusive esse problema foi constatado por ocasião das entrevistas com as prisioneiras, já que elas mesmas desconheciam a sua origem racial e não sabiam responder sobre a sua própria cor, ficando várias vezes na dúvida sobre sua própria cor, havendo inclusive receio de se autodeclararem pardas (talvez preconceito), preferindo o termo "morena".

Foi encontrado no documento Panoramas dos Territórios - Observatório da Educação, elaborado pelo Instituto Unibanco - Gerência de Gestão do Conhecimento, com dados de 2010, que a população total de Rondônia é constituída por jovens majoritariamente negros. No estado há 62,5\% de negros e, dentre os jovens, estes são $63,7 \%$. Os brancos são 35\% dos rondonienses e 33\% dos jovens. Pessoas amarelas, indígenas, ou que não declararam cor/raça somam 2,4\% da população total do estado e 2,7\% da população jovem. A proporção de negros 33,6\% é um pouco maior na faixa de 15 a 17 anos (64,5\%) (RONDÔNIA, 2017). Sobre a situação carcerária de Rondônia, ainda em relação aos mesmos dados do Infopen (2016), possuía uma massa carcerária feminina negra de $78 \%, 20 \%$ brancas e $2 \%$ amarelas, não sendo muito diferente da constatada entre as entrevistadas da Penitenciária de Ji-Paraná - RO, que ficou em 83\% a população considerada como negra.

Sobre o nível de escolaridade das prisioneiras entrevistadas, verificou-se que a maioria mal possuía o ensino fundamental completo. Do total das entrevistadas (24), 16 nem chegaram a iniciar o ensino médio, e duas haviam iniciado o curso superior.

Trazendo os dados do Infopen (2016) verificamos que 45\% possuíam o ensino fundamental incompleto; $15 \%$ concluíram o ensino fundamental; $17 \%$ possuíam ensino fundamental incompleto; $15 \%$ haviam concluído o ensino médio; $2 \%$ possuíam ensino superior incompleto; $1 \%$ concluíram o ensino superior. Desse grupo, $2 \%$ se declararam analfabetas e $3 \%$ alfabetizadas por meios informais. Se somarmos o percentual de mulheres que não chegaram a iniciar o ensino médio, chegamos à conclusão que o baixo nível escolar das prisioneiras entrevistadas é muito semelhante ao índice nacional (65\%).

E para os dados de Rondônia, em especial junho/2016, constou-se ser pouco superior ao índice nacional, ou seja, 71\% (INFOPEN, 2016) não chegaram a iniciar o ensino médio, que possibilita analisar a falta de políticas públicas voltadas à área de educação: ingresso, permanência e conclusão.

De acordo avançaram dando-nos uma noção mais contundente sobre o assunto da educação. Nos dias 
28 a 30 de abril de 2017, o governo do Estado, aplicou 366 questionários, com jovens de 13 a 25 anos, e se constatou uma realidade não muito diferente do cenário nacional, em que $60 \%$ dos jovens fora da escola têm entre 15 e 17 anos. Foram pesquisados 140 jovens no bairro Nacional; 118 no bairro Costa e Silva; 45 no São Sebastião I; 43 no São Sebastião II e 20 que residem em outros bairros de Porto Velho, capital do Estado (RONDÔNIA, 2017).

Ainda de acordo com a pesquisa, $42 \%$ dos jovens pesquisados vivem com renda familiar de apenas um salário mínimo; $31 \%$ entre um e dois salários mínimos; $17 \%$ entre três e cinco salários mínimos e 10\% acima de cinco salários mínimos. A maioria dos jovens pesquisados é do sexo masculino (57\%). Do sexo feminino representam $43 \%$. Os pesquisadores identificaram entre as maiores razões para a evasão escolar são o trabalho (32,6\%); a não aprendizagem (17,4\%); falta de transporte (17,4\%) e ausência d e gosto pelo estudo (10,6\%). Outros motivos correspondem a 22\% (RONDÔNIA, 2017). Essa realidade condiz com os índices de escolaridade das mulheres jovens encarceradas na penitenciária do município de Ji-Paraná.

No documento Observatório da Educação de Rondônia (2017), a população jovem de Rondônia é de mais de 450 mil pessoas, o que significa 29\% de toda a população do estado. Dentre os jovens, os de 15 a 17 anos (idade na qual deveriam estar cursando o ensino médio) representam 21,2\% (ou 6,14\% da população do estado, totalizando 95.920 pessoas); os de 18 a 24 representam 46,5\% da população jovem; e os de 25 a 29 anos, 32,3\% dos jovens. Embora os dados acima sejam de 2010, isso demonstra conforme os índices recentes (2017-2018) que a realidade não se altera ocasionando danos irreversíveis aos jovens (homens e mulheres), porque quanto mais o tempo passa, mais difícil o acesso ao ensino, consequentemente, a melhoria de qualificação profissional e de condições de vida digna. Os dados sobre ocupação ainda revelam que, para todas as faixas etárias, o grupo de pessoas que não estuda nem trabalha é sistematicamente maior entre as mulheres (RONDÔNIA, 2017).

Quando questionadas a respeito do seu estado civil, muitas das presidiárias entendiam que ser amasiada ou ser divorciada possuía o status de solteira. Desse modo, a resposta a essa pergunta poderia não refletir a realidade, de modo que se pedia que esclarecesse a situação de solteira. Ao comparar os dados obtidos neste trabalho com os dados do Infopen (2016) a nível nacional, verificou-se uma grande disparidade nas informações. Das 24 entrevistadas da pesquisa, uma disse que estava "ficando" com uma pessoa. Não se forçou o enquadramento desse novo status criado a uma das categorias já existentes, procurando-se respeitar a resposta dada, até porque se trata de uma expressão comum entre os jovens de hoje. O perfil das entrevistadas da pesquisa se aproxima dos dados deste Estado. Para as encarceradas no caso temos: amasiadas, 10; casadas, 6; solteiras, 4; divorciada, 1 ; outros, 3 .

Segundo o relatório Infopen (junho/2016), a nível nacional, 62\% se declararam solteiras, 23\% em união estável, $9 \%$ casadas, $2 \%$ divorciadas, $2 \%$ separadas judicialmente, e 2\% viúvas; e para o Estado de Rondônia, temos 
$31 \%$ solteiras, $49 \%$ em união estável, $16 \%$ casadas, $2 \%$ divorciadas e $2 \%$ viúvas.

Aqui uma descrição interessante para os referidos dados. Segundo documento divulgado no Relatório sobre mulheres encarceradas no Brasil (2004), desenvolvido pelos Centro pela Justiça e pelo Direito Internacional (CEJIL), Associação Juízes para a Democracia (AJD) Instituto Terra, Trabalho e Cidadania (ITCC), Pastoral Carcerária Nacional (PCN/CNBB), Instituto de Defesa do Direito de Defesa (IDDD), Centro Dandara de Promotoras Legais Popular; Associação Brasileira de Defesa da Mulher, da Infância e da Juventude (ASBRAD), Comissão Teotônio Vilela (CTV), Instituto Brasileiro de Ciências Criminais (IBCCRIM), com apoio do Comitê Latino-Americano e do Caribe para a Defesa dos Direitos da Mulher (CLADEM) e do Programa para a América Latina da International Women's Health Coalition (2004, p. 5-6):

No caso do encarceramento feminino, há uma histórica omissão dos poderes públicos, manifesta na completa ausência de quaisquer políticas públicas que considerem a mulher encarcerada como sujeito de direitos inerentes à sua condição de pessoa humana e, muito particularmente, às suas especificidades advindas das questões de gênero. Isso porque, como se verá no curso deste relatório, há toda uma ordem de direitos das mulheres presas que são violados de modo acentuado pelo Estado brasileiro, que vão desde a desatenção a direitos essenciais como à saúde e, em última análise, à vida, até aqueles implicados numa política de reintegração social, como a educação, o trabalho e a preservação de vínculos e relações familiares.

Relatório Infopen (2017, p. 35) informa ainda que no Brasil, "entre esta população, destaca-se a concentração de pessoas solteiras, que representam $60 \%$ da população prisional, seguindo a tendência observada em levantamentos anteriores. As pessoas em união estável ou casadas representam, por sua vez, $37 \%$ da população prisional”. Para Lopes, Mello e Argimon (2010, p. 3), um fator importante que foi associado significativamente com o uso de drogas, e que aumentaram a probabilidade de desenvolver a dependência química é o estado civil, sendo que as mulheres solteiras tiveram mais chances de apresentar uma dependência do que as casadas. Bem como, as encarceradas que possuíam familiares que tinham história de uso de drogas/álcool também apresentam uma maior probabilidade de desenvolver a dependência por drogas. Este dado mostra o quanto a família possui um papel fundamental no desenvolvimento psíquico dessas mulheres.

De acordo com os dados coletados com as prisioneiras entrevistadas, mais da metade delas sobreviviam com menos de 01 salário mínimo, que por ocasião da entrevista era de $\mathrm{R} \$ 937,00$. Trata-se de um valor variável, já que a maioria exercia trabalho informal. Podemos concluir que a população carcerária feminina é composta em sua maioria de pessoas de baixa renda. E aliado ao fato de que a quase totalidade das entrevistadas estão detidas por tráfico de drogas, que não deixa de ser uma via espúria de obter renda, há que se observar que talvez seja uma demonstração de revolta contra um sistema dominante e excludente (Foucault, 1975), que segrega as pessoas de baixa renda.

Entre os eixos que compõem uma análise sobre a relação entre a infraestrutura prisional e a capacidade 
de assegurar os direitos básicos da mulher presa, encontra-se a questão do exercício da maternidade no ambiente carcerário (INFOPEN MULHERES, 2016, p. 29). Nesse sentido, são contemplados pelo levantamento os dados relativos à existência de celas adequadas para gestantes, além da existência de berçário, creche e centro de referência materno-infantil. Das mulheres privadas de liberdade no Presídio de Ji-Paraná, tem-se de acordo com as entrevistadas que, $21 \%$ declararam não ter filhos. Os percentuais das que não possuem filhos não destoam daquelas informações constantes do Infopen a nível nacional (2016). A exigência de se catalogar o número de filhos e a idade deles passou a ser obrigatória, de acordo com as informações do Ministério da Justiça (Infopen Mulheres), a partir de 2014, já seguindo as diretrizes estabelecidas pelas Regras de Bangkok (Regras das Nações Unidas para o Tratamento de Mulheres Presas e Medidas Não Privativas de Liberdade para Mulheres Infratoras), que na Regra 3 dispõe que: "1. No momento do ingresso, deverão ser registrados o número e os dados pessoais dos/as filhos/as das mulheres que ingressam nas prisões. Os registros deverão incluir, sem prejudicar os direitos da mãe, ao menos os nomes das crianças, suas idades e, quando não acompanharem a mãe, sua localização e situação de custódia ou guarda." E de acordo com a Regra 22, "não se aplicarão sanções de isolamento ou segregação disciplinar a mulheres gestantes, nem a mulheres com filhos/as ou em período de amamentação"

O sistema carcerário é historicamente masculino e as regras desse modelo prisional foram adaptadas à situação feminina, o que constituiu um erro, dadas as peculiaridades do gênero. Segundo dados do INFOPEN (2016, p. 39) nacional "dada a baixa representatividade da amostra coletada, não é possível extrair conclusões para a totalidade da população prisional no Brasil. No entanto, a amostra identificou que $53 \%$ dos homens privados de liberdade não têm filhos, enquanto entre as mulheres, $74 \%$ tem pelo menos 1 filho.

Uma informação que não consta no Infopen Mulheres, de junho de 2016, são os dados a respeito dos grupos homossexuais (ou bissexuais). Embora não se possa fazer distinção a respeito da opção sexual, as informações sobre esses dados têm como finalidade a proteção e atendimento das peculiaridades e necessidades específicas desse grupo minoritário. O levantamento de dados sobre a orientação sexual junto às prisioneiras entrevistas, verificamos que 29\% se declararam homossexuais, e $8 \%$ bissexuais. Segundo Drauzio Varella, $80 \%$ das detentas no Brasil têm comportamento homossexual.

"A prisão é um experimento sádico da nossa sociedade", afirma o oncologista e escritor Drauzio Varella. Mas sem ignorar a dor provocada pelo confinamento, abandono e distanciamento dos filhos e familiares, o médico vislumbra no cárcere um espaço onde mulheres conseguem se livrar, ao menos temporariamente, da repressão machista que impera do outro lado do muro. "As mulheres são reprimidas desde que nascem, não existe nenhum outro local na sociedade onde ela é livre assim como na cadeia”, afirma Varella em entrevista ao EL PAÍS. Atrás das grades da Penitenciária Feminina da Capital, no Carandiru, convivem em harmonia diversos tipos de sapatões (homossexuais que assumem aparência masculina), entendidas (homossexuais que mantêm aparência feminina) e mulheríssimas (heterossexuais que ocasionalmente tem relações com mulheres) - os termos foram criados pelas próprias presas. A exceção são as aborteiras, que precisam ficar em celas isoladas 
(CAVALCANTI, 2017).

De acordo com Varella (2017) em entrevista para Fernando Cavalcanti:

O comportamento homossexual entre as presas é muito mais abrangente do que aparenta no início. Isso leva tempo para perceber. Porque essas relações femininas são mais sutis. $\mathrm{Na}$ cadeia de homens você percebe que alguns presos são notadamente homossexuais. Mesmo que não sejam travestis, são homossexuais, andam com outro homem que você sabe que é o marido dele. Na cadeia feminina não. Entre elas as relações adquirem uma outra dinâmica. Um número muito grande de presas tem comportamento homossexual, é a maioria esmagadora! Gira em torno de $80 \%$, talvez até mais.

Para Barcinski (2012, p. 437), "entender a relação homossexual como pautada primordialmente no afeto corrobora a imagem do feminino atrelada ao cuidado e ao empenho na manutenção de relações afetivas". Gilligan (1982); Barcinski (2012)) sugere que a "ética do cuidado" que caracteriza as mulheres é centrada na atenção às necessidades do outro e à preservação dos relacionamentos afetivos. Também focada no afeto como dimensão essencialmente feminina, Miller (1986) afirma que a mulher constrói a sua identidade servindo aos outros, desenvolvendo a ideia de que a sua vida deve ser guiada pelos desejos, necessidades e vontades daqueles ao seu redor.

O oncologista e escritor Drauzio Varella, no entanto, salienta: "O único lugar em que a mulher tem liberdade sexual é na cadeia. Não existe nenhum outro local na sociedade onde ela é livre assim. As mulheres são reprimidas desde que nascem: a menina de dois anos de idade senta com a perna aberta e a mãe diz "fecha a perna”. Essa repressão ocorre o tempo inteiro. Comportamentos que são aceitos e naturalizados para um homem são execrados para mulheres. E no presídio, sem os homens, não existe essa repressão social. Isso faz com que elas tenham o comportamento social que desejarem ter. A homossexualidade está muito mais próxima do universo feminino do que do masculino, e o que a cadeia faz é criar condições que dão liberdade para que a mulher se comporte do jeito que ela achar melhor, sem repressão. E do outro lado você tem a solidão. Essa mulher vive praticamente sozinha, pouquíssimas recebem visitas íntimas, apenas umas 120 de um total de 2.200”.

\section{Direitos Humanos na prática jurisdicional a favor das condenadas no caso reverso da Lei Maria da Penha}

A condenação de mulheres que cometeram crimes, por terem sido coagidas ou obrigadas pelo companheiro ou terceiro, revela múltiplas violências. Inicialmente, porque já foram vítimas pelo companheiro ou por alguém que detém sobre elas algum poder, talvez por várias vezes; em segundo lugar, são obrigadas a manterem-se caladas, sem poder revelar quem lhes obrigou a praticar a infração penal, como condição para a sua integridade física; em terceiro, porque tal fato, por não poder ser objeto de prova no processo, acabam sendo condenadas pelo juiz; em quarto, permanecem em sistemas prisionais que não estão adaptadas para as suas 
condições próprias femininas; em quinto, porque passam a ter contato com outras prisioneiras, muitas vezes condenadas por crimes graves; em sexto lugar, por estarem em ambiente propício para a dependência química; em sétimo, quando mães, ficam distantes de seus filhos; em oitavo lugar, perdem a maior parte de sua vida produtiva e reprodutiva na prisão; em nono, por terem sido presas, permanecem com um dívida com o companheiro ou com o terceiro que as obrigou a praticar a infração penal; em décimo lugar, por terem sido condenadas em regime fechado, pela prática de tráfico de drogas, como é a maioria das presidiárias, o tempo de condenação é longo e é a causa de distúrbios de comportamento, transtornos psiquiátricos e dificulta a ressocialização, como afirma Dráuzio Varela (2017, p. 39); em décimo primeiro lugar, por estarem muitas vezes em condições insalubres, acabam contraindo doenças; em décimo segundo, o Poder Público nem sempre atende às necessidades mínimas básicas das prisioneiras. Salienta-se aqui, por fim, que não poucas vezes são elas vítimas de violência, física, psicológica e moral, de todos os sujeitos intervenientes da fase de inquérito policial e processo criminal.

\section{CONSIDERAÇÕES FINAIS}

A história de vida das entrevistadas está atrelada à violência, não somente sob o aspecto familiar (violência física e psíquica), mas também sob o aspecto social e econômico: viviam na informalidade, em subempregos; a maioria com renda variável e abaixo de um salário mínimo; baixo nível de escolaridade e em família sem estrutura que internalizasse as regras de convivência social; acesso fácil às drogas, principalmente, na fase da adolescência.

Analisando a violência que se sujeitaram as mulheres encarceradas em Ji-Paraná (RO), nota-se que a violência existiu antes e durante a fase de inquérito policial e processo judicial. O silêncio no caso representa a moeda de troca pela vida, mas a violência não termina aí. Ela se perpetua não só durante o cumprimento da pena, como também depois de cumprida, porque sempre poderá surgir a oportunidade, enquanto não prescrita a infração penal, de penalizar o principal responsável criminalmente. Há a necessidade de recalque desse fato. Nos casos analisados, várias mulheres foram vítimas de violência, por membros da família ou por terceiro. Essas formas de violência não podem aparecer no processo. Elas devem manter o sigilo do nome dos verdadeiros responsáveis, de modo que acabam suportando a pena criminal aplicada pela justiça, que não deixa de ser uma violência, além de ter que suportar todos os efeitos de uma condenação que perdura até o fim da prescrição do direito de punir do estado. O sentimento de medo é sofrimento psicológico, até porque para ela é real. O medo é um instrumento de poder muito eficaz nesses casos.

Apesar da Lei Maria da Penha ter sido elogiada e ser considerada revolucionária em relação ao combate à 
violência contra as mulheres no Brasil, nos casos em que ela foi obrigada a praticar um crime e manter-se em silêncio, em razão do medo imposto pelo autor da agressão, pouco ou nada se pode fazer se a situação não for revelada à autoridade judiciária na medida em que as decisões estão pautadas em provas. A Lei n. 9.807/1999 ${ }^{10}$, para ser aplicada, no caso, necessita que haja colaboração, efetiva e voluntária do réu (da vítima) com a investigação policial, fato este impeditivo da revelação da verdade por parte da vítima. Todavia, há mecanismos que podem ser determinados pelo magistrado na descoberta dessa situação de violência imposta pelo silêncio da vítima, mantendo as informações em sigilo (arts. 20 e 201, ambos do Código de Processo Penal) e fora do processo. Ainda que não se possa punir o autor da agressão, até porque poderia atuar em desfavor da vítima, pois a ameaça poderia ser concretizada, há a necessidade do Poder Público de atuar em benefício dessas mulheres que não são poucas nessa situação.

A condenação criminal pressupõe a livre manifestação da vontade do agente na prática da infração penal. Na pesquisa levada a efeito na Penitenciária Feminina de Ji-Paraná-RO, com o intuito de analisar a invisibilidade da população carcerária feminina e seu progressivo e alarmante aumento no país, constatou-se a presença de algumas mulheres condenadas que praticaram crimes para beneficiar terceiros com quem guardam algum vínculo de dependência hierárquica, econômica, psicológica e emocional. A lei do silêncio foi imposto pelo terceiro a essas mulheres como moeda de troca pela manutenção de sua integridade física. Tais informações, obviamente, não apareceram e não podem constar do processo. A prática desses crimes por essas mulheres não decorre da livre manifestação de vontade, e a sua condenação e manutenção no cárcere, em regime fechado, constitui não só medida de injustiça, mas grave e múltiplas formas de violência contra as mulheres; e a Lei Maria da Penha, elogiada internacionalmente, se entremostra, no caso, pouco eficaz para resgatar a dignidade e dar efetiva proteção e amparo a essas mulheres, e em oposição às normas Internacionais de Direitos Humanos que coíbem quaisquer formas de discriminação e violência contra as mulheres.

\footnotetext{
${ }^{10}$ Estabelece normas para a organização e a manutenção de programas especiais de proteção a vítimas e a testemunhas ameaçadas, institui o Programa Federal de Assistência a Vítimas e a Testemunhas Ameaçadas e dispõe sobre a proteção de acusados ou condenados que tenham voluntariamente prestado efetiva colaboração à investigação policial e ao processo criminal.
} 


\section{VIOLENCE AS AN INSTRUMENT OF POWER IN SOCIAL RELATIONSHIPS AND AN INSTRUMENT OF DOMINATION}

\section{Abstract}

This paper has as its theme the phenomenon of the female prisoner population growth in the correctional system in Brazil. In order to identify the intern women contingent and for the profile analysis, the study was limited to women imprisoned in the State of Rondônia, using as starting point the Report InfopenMulheres, 2nd edition, published by the Ministry of Justice and Public Security and the National Penitentiary Department, in 2017, on the female prisoner population in each unit of the Federation. The study informs that Rondônia counts 721 women deprived of liberty, occupying the 16th place on the list (2017). It analyzes the Maria da Penha Law (law n. 11340/2006), which disposes, according to its summary, mechanisms that intend to withstand domestic and familiar violence against women, on the terms of Article 226, Chapter 8th, of the Federal Constitution of 1988, of the Convention on the Elimination of all Forms of Discrimination Against Women and the Inter-American Convention to Prevent, Punish and Eradicate Violence Against Women, among other provisions. However, even though approved, many barriers still surround the application of Law n. 11340/2006, of material (absence or inefficacy of services) and personal order, which go from the ignorance of the law by parts of the population to the diversity of understanding among law enforcers. The qualitative research was performed in two phases, being the first one the adoption of methodological procedures of documental and bibliographic basis, emphasizing the human rights and the Maria da Penha Law; and the second one, of participative observation, with the application of 24 questionnaires and interviews made in the female penitentiary of Ji-Paraná (Rondônia), in the period of December 17, 2017 to January 14, 2018 and January 21, 2018, with the interns who authorized to participate. The intention was to collect the following data: state of origin, age group, color or race, schooling degree, marital status, socio-economic condition, in relation with minimum wage, number of children, sexual preference -- in order to trace the socio-demographic profile of the female population deprived of liberty in that penal establishment, for analyses and future proposals of attendance to their rights as women.

Keywords: Women. Imprisonment. Profile. Human rights. Maria da Penha Law. 


\section{REFERENCIAS}

BARCINSKI, Mariana. Expressões da homossexualidade feminina no encarceramento: o significado de se "transformar em homem" na prisão. Psico-USF, Bragança Paulista, v. 17, n. 3, p. 437-446, set./ dez. 2012, p. 437446.

BRASIL, Ministério da Justiça. Levantamento Nacional de Informações Penitenciárias. INFOPEN Mulheres, 2014.

Constituição 1988. Constituição da República Federativa do Brasil.

Código de Processo Penal. (Decreto-lei n 3.689, de 3 de outubro de 1941).

Código Penal. (Decreto-lei no 2.848, de 7 de dezembro de 1940.).

Lei n 9.099, de 26 de setembro de 1995. Dispõe sobre os Juizados Especiais Cíveis e Criminais e dá outras providências.

Conselho Nacional de Justiça (CNJ). O Poder Judiciário na aplicação da Lei Maria da Penha (2017).

http://www.cnj.jus.br/files/conteudo/arquivo/2017/10/ba9a59b474f22bbdbf7cd4f7e3829aa6.pdf, acessado em 30.06.2018.

Conselho Nacional de Justiça (CNJ). Regras de Bangkok: Regras das Nações Unidas para o Tratamento de Mulheres Presas e Medidas Não Privativas de Liberdade para Mulheres Infratoras. Departamento de Monitoramento e Fiscalização do Sistema Carcerário e do Sistema de Execução de Medidas Socioeducativas. Brasília: Conselho Nacional de Justiça, 2016, 1ª ed., 80 p.

Departamento Penitenciário Nacional - DEPEN. Levantamento Nacional de Informações Penitenciárias. INFOPEN. Organização: Thandara Santos. Colaboração: Marlene Inês da Rosa et. al. Brasília: Ministério da Justiça e Segurança Pública. 2017. Disponível em: http://depen.gov.br/DEPEN/noticias-1/noticias/infopenlevantamento-nacional-de-informacoes-penitenciarias-2016/relatorio_2016_22111.pdf, acessado em 30.06.2018

L. Departamento Penitenciário Nacional - DEPEN. Levantamento Nacional de Informações Penitenciárias. INFOPEN Mulheres. Organização: Thandara Santos. Colaboração: Marlene Inês da Rosa et. al. Brasília: Ministério da Justiça e Segurança Pública. 2017. Disponível em: http://depen.gov.br/DEPEN/depen/sisdepen/infopen-mulheres/infopenmulheres_arte_07-03-18.pdf, acessado em 30.06.2018.

Presidência da República. Casa Civil. Subchefia para assuntos jurídicos. Código de Processo Penal. 
Disponível em: http://www.planalto.gov.br/ccivil_03/Decreto-Lei/Del3689.htm, acessado em 10.03.2018. Presidência da República. Casa Civil. Subchefia para assuntos jurídicos. Lei n. 8.906/94 - Estatuto da Advocacia. Disponível em: http://www.planalto.gov.br/ccivil_03/Leis/L8906.htm, acessado em 09.03.2018. Presidência da República. Casa Civil. Subchefia para assuntos jurídicos. Lei n. 9.807/1999. Disponível em: http://www.planalto.gov.br/ccivil_03/leis/19807.htm, acessado em 09.03.2018.

Presidência da República. Lei de Execução Penal no 7.210, 1984. Disponível em: http://www.planalto.gov.br/ccivil_03/leis/L7210.htm Acesso em: 21 ou. 2016.

Superior Tribunal de Justiça. Conflito de Competência no 103.813. MG (2009/0038310-8).

Disponível

em: https://ww2.stj.jus.br/processo/revista/documento/mediado/?componente=ATC\&sequencial=5549047\&nu m_registro $=200900383108 \&$ data $=20090803 \&$ tipo $=5 \&$ formato $=P D F$, acessado 21 out 2016.

Supremo Tribunal Federal. ADPF 132/RJ. Disponível em: http://redir.stf.jus.br/paginadorpub/paginador.jsp?docTP=AC\&docID=628633, acessado em 11 jul. 2017.

Supremo Tribunal Federal. HC 143.641/SP. Disponível em: http://www.stf.jus.br/arquivo/cms/noticiaNoticiaStf/anexo/HC14364lfinal3pdfVoto.pdf. Acesso em: 20 ago. 2017.

Ação Direta de Inconstitucionalidade. ADI n. 4424/DF. Supremo Tribunal Federal (STF) em 2012.

CAVALCANTI, Fernando. Prisioneiras: $80 \%$ das detentas têm comportamento homossexual nos presídios brasileiros. Disponível em: http://www.umoutroolhar.com.br/2017/07/prisioneiras-80-das-detentas-temcomportamento-homossexual.html. Acesso em: 13 jul.2018.

CHAUÍ, Marilena S. Sobre o medo. In: NOVAES, A. Os sentidos da paixão. São Paulo, Companhia das Letras, 1987.

CIDH. O relatório Maria da Penha. Disponível em: https://cidh.oas.org/annualrep/2000port/12051.htm. Acesso em: 10 jul 2018.

DUARTE, Clarice Seixas. A educação como um direito fundamental de natureza social. Educ. Soc., Campinas, vol. 28, n. 100 - Especial, p. 691-713, out. 2007 Disponível em: http://www.scielo.br/pdf/es/v28n100/a0428100. Acesso em: 10 jul. 2018. 
CUNHA, Rogério Sanches e PINTO, Ronaldo Batista. Violência doméstica (Lei Maria da Penha): Lei n. 11.340/2006. Comentada artigo por artigo. São Paulo: Editora Revista dos Tribunais. 2007.

DIAS, Maria Berenice, A Lei Maria da Penha na Justiça: A efetividade da Lei11.340/2006 de combate à violência doméstica e familiar contra a mulher. São Paulo: Revista dos Tribunais, 2008.

ELIAS, Norbert. O processo civilizador. Formação do Estado e Civilização. Teoria dos processos civilizadores. Tradução de Ruy Jungmann. V. 2. Revisão, apresentação e notas de Renato Janine Ribeiro. Rio de Janeiro: Jorge Zahar Editor, 1993.

FOUCAULT, Michel. Vigiar e Punir - História da violência nas prisões. 34. Ed. Petrópolis, RJ: Vozes, 2007.

FOUCAULT, Michel. Vigiar e Punir: Nascimento da prisão. Tradução de Raquel Ramalhete, 42 ed. Petrópolis, RJ, Editora Vozes, 2014

GOMES, Luiz Flávio. A impunidade generalizada no Brasil. Disponível em: http://www.ipclfg.com.br/artigosdo-prof-lfg/a-impunidade-generalizada-no-brasil/ . Acesso em: 13 jul. 2018.

IBGE. Panoramas. Cidade. disponível em: https://cidades.ibge.gov.br/brasil/ro/panorama. Acesso em: 08 jun. 2018.

JELIN, Elizabeth. Mulheres e Direitos Humanos. Tradução: Irene Giambiagi. Estudos feministas. Ano 02, 1º semestre de 1994, p. 117-149. Disponível em: https://periodicos.ufsc.br/index.php/ref/article/viewFile/16293/14834, acessado em 05.07.2018.

LOPES, Regina Maria Fernandes; MELLO, Daniela Canazaro de; ARGIMON, Irani I. de Lima. Mulheres encarceradas e fatores associados a drogas e crimes. Ciênc. Cogn. vol.15 no.2 Rio de Janeiro ago. 2010. Disponível em: http://pepsic.bvsalud.org/scielo.php?script=sci_arttext\&pid=S1806-58212010000200011. Acesso em: 10 jul. 2018.

MADEIRA, Maria Zelma de Araújo e COSTA, Renata Gomes da. Desigualdades de gênero, poder e violência: uma análise da violência contra a mulher. O Público e o Privado - Revista do Programa de Pós- 
Graduação em Sociologia da Universidade Estadual do Ceará, n. 19, Janeiro/Junho - 2012, p. 79-99. Disponível em: file:///Users/macair/Downloads/342-1392-1-PB\%20(1).pdf. Acesso em: 9 mar.2018.

MELO, juliana. Dossiê Punição e Controle Social: degradações carcerárias em América Latina e Europa. V. 02, N. 2, Jul.-Dez., 2016.

MENDONÇA, José Ricardo Costa de e DIAS, Sônia Maria Rodrigues Calado. De French e Raven (1959) ao modelo poder/interação de influência interpessoal: uma discussão sobre poder e influência social. FGV, Cadernos EBAPE.BR, v. 4, n. 4, dez/2006, disponível em: http://www.scielo.br/pdf/cebape/v4n4/v4n4a09.pdf, acessado em 09.03.2018.

MIRABETE, Júlio Fabrini. Execução Penal. 10. ed. São Paulo: Atlas, 2002.

MOHAMED, André Nascimento. O Direito Penal do autor no ordenamento jurídico brasileiro. Disponível em:

http://www.emerj.tjrj.jus.br/paginas/trabalhos_conclusao/1semestre2010/trabalhos_12010/andremohamed. pdf, acessado em 20.06.2018.

OEA. Comissão Interamericana de Direitos Humanos. Relatório 54/01. Caso 12.051, Maria da Penha Maia Fernandes, Brasil, 4 de abril de 2001. Disponível em: https://cidh.oas.org/annualrep/2000port/12051.htm, acessado em 09.03.2018.

ONU. Convenção Americana Sobre Direitos Humanos. 1969. Disponível em: https://www.cidh.oas.org/basicos/portugues/c.convencao_americana.htm. Acesso em: 20 mai. 2017.

ONU. Declaração Universal dos Direitos Humanos. Paris: 1948.

ORGANIZAÇÃO DOS ESTADOS AMERICANOS. Comissão Interamericana de Direitos Humanos. Convenção interamericana para prevenir, punir e erradicar a violência contra a mulher: Convenção de Belém do Pará. Disponível em: http://www.cidh.org/Basicos/Base8.htm

ORGANIZAÇÃO DAS NAÇÕES UNIDAS. CEDAW. Convention on the Elimination of All Forms of vol.11, no. 04, Rio de Janeiro, 2018.pp. 3092-3127 


Discrimination against Women. Disponível em:

http://www.un.org/womenwatch/daw/cedaw/text/econvention.htm

PASINATO, Wânia. Acesso à Justiça e Violência Doméstica e Familiar contra as Mulheres: as Percepções dos Operadores Jurídicos e os Limites para a Aplicação da Lei Maria da Penha. São Paulo: Revista Direito GV. Jul/dez de 2015. Disponível em: , acessado em 15.02.2017.

PEIXOTO, Paula Carvalho. Vítimas encarceradas: histórias de vidas marcadas pela violência doméstica e pela criminalidade feminina. São Paulo: IBCCRIM, 2017, p. 123.

PITANGUY, Jacqueline Pitanguy. Conselho Curador do Fundo Brasil de Direitos Humanos. Disponível em: http:// www.fundodireitoshumanos.org.br. Acesso em: 12 jul. 2018.

PITANGUY, Jacqueline. Os Direitos Humanos das Mulheres. Disponível em: http://www.fundodireitoshumanos.org.br/downloads/artigo_mulheres_jacpit.pdf. Acesso em: 17 jul. 2017.

PRADO, Luiz Regis. Curso de Direito Penal Brasileiro. Volume 1: parte geral. São Paulo: Editora Revista dos Tribunais, 5 ed. rev., 2005.

RAVEN, B. H. Social influence and power. In: STEINER, I. D.; FISHBEIN, M. (Ed.). Current studies in social psychology. New York: Wiley, 1965. p.399-444. In: MENDONÇA, Ricardo; DIAS, Sônia Maria Rodrigues Calado. Cad. EBAPE.BR vol.4 no.4 Rio de Janeiro Dec. 2006.

RAMONEDA, Josep. Apologia del present: assaigs de fi de segle (Apology for the Present: Essays for the End of the Century, 1989. Disponível em: https://www.publicspace.org/multimedia/-/post/josep-ramoneda. Acesso em: 15 ago. 2018 .

RIFIOTIS, Theophilos. Violência, Justiça e Direitos Humanos: reflexões sobre a judicialização das relações sociais no campo da "violência de gênero". Cadernos pagu(45), jul/dez de 2015. Disponível em: http://www.scielo.br/pdf/cpa/n45/0104-8333-cpa-45-00261.pdf. Acesso em: 02 fev. 2017.

RONDÔNIA. Evasão Escolar. Pesquisa identifica que 42\% dos jovens fora da escola em Porto Velho têm renda 
familiar de um salário mínimo. Disponível em: http://www.rondonia.ro.gov.br/pesquisa-identifica-que-42-dosjovens-fora-da-escola-em-porto-velho-tem-renda-familiar-de-um-salario-minimo/. Acesso em: 13 jul 2018.

RONDÔNIA. Panorama dos Territórios. Observatório da Educação de Rondônia. Disponível em: https://observatoriodeeducacao.org.br/wp-content/uploads/2017/03/Panoramas_RONDONIA.pdf. Acesso em: 13 jul. 2018.

SILVA, Renata Alves da. As relações de poder e a violência contra a mulher: na saúde e na doença, na alegria e na tristeza. Disponível em: http://www.gepsexualidades.com.br/resources/anais/6/1467423059_ARQUIVO_AsRelacoesdePodereaViol enciaContraaMulhernasaudeenadoenca,naalegriaenatristeza.pdf. Acesso em: 9 mar. 2018.

SOUZA, Daniel Barbosa L. F. C. de. Famílias Plurais ou espécies de família. Disponível em: http://www.conteudojuridico.com.br/artigo,familias-plurais-ou-especies-de-familias,25712.html, acessado em 11.06.2018.

TOLEDO, Francisco de Assis. Princípios Básicos de Direito Penal. São Paulo: Saraiva, $5^{a}$ edição, $6^{a}$ tiragem, 1999.

VARELLA, Drauzio. Prisioneiras. São Paulo: Companhia das Letras, 1a ed., 2017.

ZAFFARONI, Raul Eugênio; PIERANGELI, José Henrique. Manual de Direito Penal Brasileiro. Parte Geral. São Paulo: Editora Revista dos Tribunais, 1997.

Trabalho enviado em 29 de outubro de 2018

Aceito em 03 de novembro de 2018 